\title{
A Bimetallic Tantalum-Zinc Complex with an Ancillary Aryldiamine Ligand as Precursor for a Reactive Alkylidyne Species: Alkylidyne-Mediated C-H Activation and a Palladium-Mediated Alkylidyne Functionalization
}

\author{
Hendrikus C. L. Abbenhuis, ${ }^{\dagger}$ Nantko Feiken, ${ }^{\dagger}$ Henk F. Haarman, ${ }^{\dagger}$ \\ David M. Grove, ${ }^{\dagger}$ Ernst Horn, ${ }^{\ddagger}$ Anthony L. Spek, ${ }^{\ddagger}$ Michel Pfeffer, ${ }^{\S}$ and \\ Gerard van Koten *, \\ Department of Metal-Mediated Synthesis, Debye Research Institute, and Department of \\ Crystal and Structural Chemistry, Bijvoet Research Institute, University of Utrecht, \\ Padualaan 8, $3584 \mathrm{CH}$ Utrecht, The Netherlands, and Laboratoire de Synthèses \\ Métallo-induites, Unité Associée au CNRS No. 416, Université Louis Pasteur, \\ 4 Rue Blaise Pascal, 67008 Strasbourg Cedex, France
}

Received February 22, 1993

The 1:1 reaction of $\mathrm{TaCl}_{2}\left\{\mathrm{C}_{6} \mathrm{H}_{3}\left(\mathrm{CH}_{2} \mathrm{NMe}_{2}\right)_{2}-2,6\right\}(=\mathrm{CH}-t-\mathrm{Bu})$ with neopentylzinc chloride affords the bimetallic complex $\mathrm{TaCl}_{2}\left\langle\mathrm{C}_{6} \mathrm{H}_{3}\left(\mathrm{CH}_{2} \mathrm{NMe}_{2}\right)_{2}-2,6\right\}(\mu-\mathrm{C}-t-\mathrm{Bu})(\mu-\mathrm{ZnCl})(2)$ in high yield. Crystals of 2 belong to the space group $P 22_{1} 2_{1} 2_{1}$ with $a=9.725$ (2) $\AA, b=10.436(2) \AA, c=20.766(3)$ $\AA, Z=4, M_{\mathrm{r}}=613.11, V=2107.5(7) \AA^{3}, \rho($ calcd $)=1.932 \mathrm{~g} \cdot \mathrm{cm}^{-3}$. The pentacoordinate tantalum center has a coordination geometry between trigonal bipyramidal and square pyramidal while the zinc center has a distorted tetrahedral ligand array; the alkylidyne functionality and the aryl ipso-carbon bridge between the zinc and tantalum centers. The p-orbital at $\mathrm{C}_{i p s o}$ of the aryldiamine ligand forms a 2-electron bond to the zinc center, and this aryldiamine ancillary thus functions as an 8-electron donor. The reaction of 2 with tmeda at $60^{\circ} \mathrm{C}$ leads to elimination of zinc chloride and formation of the alkylidene complex $\mathrm{TaCl}\left\{\mathrm{C}_{6} \mathrm{H}_{3}\left(\mathrm{CH}_{2} \mathrm{~N}(\mathrm{Me}) \mathrm{CH}_{2}\right)-2-\left(\mathrm{CH}_{2}-\right.\right.$ $\left.\left.\mathrm{NMe}_{2}\right)-6\right\}(=\mathrm{CH}-t-\mathrm{Bu})$; this is an alkylidyne-mediated activation reaction of a methyl $\mathrm{C}-\mathrm{H}$ bond in a $\mathrm{NMe}_{2}$ group. In the presence of $\left[\mathrm{Pd}\left(\mathrm{C}_{6} \mathrm{H}_{4} \mathrm{CH}_{2} \mathrm{NMe}_{2}-2\right)(\mu-\mathrm{X})\right]_{2}(\mathrm{X}=\mathrm{Cl}, \mathrm{I})$ the reaction of bimetallic 2 with tmeda $\left[\mathrm{Me}_{2} \mathrm{~N}\left(\mathrm{CH}_{2}\right)_{2} \mathrm{NMe}_{2}\right]$ appears to generate $\mathrm{TaCl}_{2}\left(\mathrm{C}_{6} \mathrm{H}_{4} \mathrm{CH}_{2} \mathrm{NMe}_{2}-2\right)[=\mathrm{C}(t-$ $\left.\mathrm{Bu})\left\{\mathrm{C}_{6} \mathrm{H}_{3}\left(\mathrm{CH}_{2} \mathrm{NMe}_{2}\right)_{2}-2,6\right\}\right]$ and, as such, is an unanticipated, new palladium-mediated alkylidyne functionalization reaction.

\section{Introduction}

The reactivity of the metal-carbon triple bond in carbyne complexes ${ }^{1}$ has been studied by several groups. Principal aims have been either the use of the carbyne fragment as a building block in organic synthesis or the use of the metal-carbon triple bond as a sterically hindered heteroacetylene, for example, in cluster synthesis. ${ }^{2,3}$ In particular there has been extensive employment of the isolobal analogy 4 between group 6 metallacarbynes and alkynes to guide the synthesis of polymetallic compounds, whereby one adds $\mathrm{M}(\equiv \mathrm{CR})(\mathrm{L})(\mathrm{CO})_{2}(\mathrm{~L}=6$-electron ligand) complexes to coordinatively unsaturated metal species. ${ }^{2}$ Very few studies, however, report the use of this concept to achieve C-C bond formation. ${ }^{5,6}$ Recently, it has been shown that low oxidation state tungsten and molybdenum carbyne complexes containing either cyclopentadienyl or tripod ligands can react with $\left[\mathrm{Pd}\left(\mathrm{C}_{6} \mathrm{H}_{4}\right.\right.$ $\left.\left.\mathrm{CH}_{2} \mathrm{NMe}_{2}-2\right)(\mu-\mathrm{X})\right]_{2}(\mathrm{X}=\mathrm{Cl}, \mathrm{I})$ to give organometallic products wherein there is a new $\mathrm{C}-\mathrm{C}$ bond formed through insertion of a W $\equiv \mathrm{C}$ or $\mathrm{Mo} \equiv \mathrm{C}$ bond into a $\mathrm{Pd}-\mathrm{C}$ bond. ${ }^{6}$ Compared to such low oxidation state carbyne complexes, higher oxidation state alkylidyne species should have a

\footnotetext{
* To whom correspondence should be addressed.

$\uparrow$ Debye Research Institute, University of Utrecht.

$\$$ Bijvoet Research Institute, University of Utrecht.

Universite Louis Pasteur.

(1) Fischer, H., Hoffmann, P., Kreissl, F. R., Schrock, R. R., Schubert, U., Weiss, K., Eds. Carbyne Complexes; Verlag Chemie: Weinheim, 1988. (2) (a) Stone, F. G. A. Angew. Chem. 1984, 85, 96. (b) Davies, S. J.; Howard, J. A. K.; Pilotti, M. U.; Stone, F. G. A. J. Chem. Soc., Dalton Trans. 1989, 2289 and references cited therein.
}

more reactive nucleophilic $\mathrm{M} \equiv \mathrm{C}$ unit $^{7,8}$ that may be more likely to participate in $\mathrm{C}-\mathrm{C}$ bond formation reactions. However, reactions between high oxidation state metal alkylidyne complexes and late transition metal species containing a metal-to-carbon bond do not seem to have been investigated so far.

In a previous paper, we reported the synthesis of a high oxidation state tantalum alkylidene complex, $\mathrm{TaCl}_{2}$ $\left\{\mathrm{C}_{6} \mathrm{H}_{3}\left(\mathrm{CH}_{2} \mathrm{NMe}_{2}\right)_{2}-2,6\right\}(=\mathrm{CH}-t-\mathrm{Bu})(1),{ }^{9 b}$ that contains a monoanionic aryldiamine ancillary ligand that markedly enhances the kinetic stability of this complex by forming intramolecular $\mathrm{Ta}-\mathrm{C}-\mathrm{C}-\mathrm{C}-\mathrm{N}$ chelate rings. In this

(3) In organotantalum chemistry, however, a number of heterobimetallic and -polymetallic complexes have been reported, but none of the synthetic methods employed here involves a reaction with a tantalum alkylidyne complex. Heterometallics that contain an 18-electron dicyclopentadienyltantalum fragment are well-represented. ${ }^{\text {and }}$ - The remaining heterometallic tantalum complexes reported are either saltlike derivatives of the hexacarbonyltantalate anion, ${ }^{3-h}$ Lewis-acid stabilized tantalum alkylidene $e^{3 \mathrm{~h}}$ and alkylidyme complexes ${ }^{10,18}$ or heterobimetallic complexes in which a specially designed ligand system binds two metal centers; ligand systems used in this field are (oxyalkyl)phosphines ${ }^{3 \mathrm{j}}$ and a bis. (tetramethylcyclopentadienyl)ethane ligand. ${ }^{31}$ (a) Budzelaar, P. H. M.; van der Zeijden, A. A. H.; Boersma, J.; van der Kerk, G. J. M.; Spek, A. L.; Duisenberg, A. J. M. Organometallics 1984, 3, 159. (b) Harris, D. H. Keppie, S. A.; Lappert, M. F. J. Chem. Soc., Dalton Trans. 1973, 1653. (c) Perrey, D.; Leblanc, J. C.; Moise, C.; Martin-Gil, J. J. Organomet. Chem. 1991, 412, 363. (d) Jacobsen, E. N.; Goldberg, K. I.; Bergmann, R. G. J. Am. Chem. Soc. 1988, 110, 3706. (e) Werner, R. P. M.; Filbey, A. H.; Manastyrakyj, S. A. Inorg. Chem. 1964, 3, 298. (f) Ellis, J. E.; Davidson, A. Inorg. Synth. 1976, 16, 68. (g) Davidson, A.; Ellis, J. E. J. Organomet. Chem. 1972, 36, 113. (h) Keblys, K. A.; Dubeck, M. Inorg. Chem. 1964, 3, 1646. (i) Schrock, R. R.; Sharp, P. R. J. Am. Chem. Soc. 1978, 100, 2389. (j) Baxter, S. M.; Wolczanski, P. T. Organometallics 1990, 9, 2498. (k) Buzinkai, J. F.; Schrock, R. R. Inorg. Chem. 1989, 28, 2837. 
Scheme I. Routes to the Bimetallic Tantalum-Zinc Complex 2

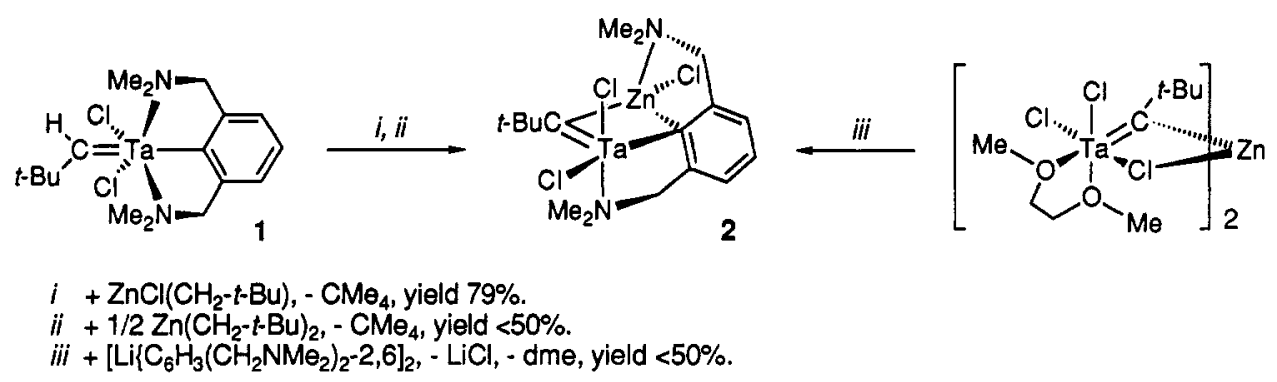

paper we report a synthetic approach that converts 1 into a Lewis-acid stabilized alkylidyne species. We also show examples of various tantalum alkylidyne-mediated reactions, including the intramolecular activation of a $\mathrm{C}-\mathrm{H}$ bond in a $\mathrm{NMe}_{2}$ group and the unprecedented functionalization of an alkylidyne fragment obtained with a cyclometalated palladium species.

\section{Results}

Synthesis of a Bimetallic Tantalum-Zinc Complex. The 1:1 reaction of the alkylidene complex $\mathrm{TaCl}_{2}$ $\left\{\mathrm{C}_{6} \mathrm{H}_{3}\left(\mathrm{CH}_{2} \mathrm{NMe}_{2}\right)_{2}-2,6\right\}(=\mathrm{CH}-t-\mathrm{Bu})(1)$ with neopentylzinc chloride, a mild base, leads to alkylidene $\alpha$-H abstraction that affords the red, bimetallic, neopentylidyne complex $\mathrm{TaCl}_{2}\left\{\mathrm{C}_{6} \mathrm{H}_{3}\left(\mathrm{CH}_{2} \mathrm{NMe}_{2}\right)_{2}-2,6\right\}(\mu-\mathrm{C}-t-\mathrm{Bu})(\mu-\mathrm{ZnCl})(2)$ in high yield (Scheme I, route $i$ ). When, instead, this $\alpha-\mathrm{H}$ abstraction is performed with 0.5 equiv of dineopentylzinc, complex 2 is formed in less than $50 \%$ yield (Scheme I, route $i$ ). In an alternative approach, the transmetalation reaction of the trimetallic ditantalum-zinc complex $\left\{\mathrm{TaCl}_{2}(\mu-\mathrm{C}-t-\mathrm{Bu})(\mathrm{dme})\right\}_{2} \mathrm{Zn}(\mu-\mathrm{Cl})_{2}{ }^{10}\left(\mathrm{dme}=\mathrm{MeO}\left(\mathrm{CH}_{2}\right)_{2-}\right.$ $\mathrm{OMe})$ with the aryllithium compound $\left[\mathrm{Li}\left\{\mathrm{C}_{6} \mathrm{H}_{3}\left(\mathrm{CH}_{2^{-}}\right.\right.\right.$ $\left.\left.\left.\mathrm{NMe}_{2}\right)_{2}-2,6\right\}\right]_{2}{ }^{11}$ also affords bimetallic 2 but in low yield (Scheme I, route iii). Bimetallic 2 can be easily isolated from the reaction mixtures by evaporation of the solvent and subsequent extraction of the solid residue with benzene; the complex crystallizes in large red needles from benzene/pentane solutions. The solid compound is thermally stable to at least $80^{\circ} \mathrm{C}$ and can be safely handled for short periods in air. Cryoscopic molecular weight measurements show that 2 is monomeric in benzene.

The ${ }^{1} \mathrm{H}(200.13 \mathrm{MHz})$ and ${ }^{13} \mathrm{C}(50.32 \mathrm{MHz}) \mathrm{NMR}$ data of 2 in $\mathrm{C}_{6} \mathrm{D}_{6}$ are not temperature dependent to at least 80 ${ }^{\circ} \mathrm{C}$ (the highest temperature employed) and are consistent with its formulation as shown in Scheme I. The ${ }^{1} \mathrm{H}$ NMR spectrum contains four anisochronous methyl resonances for the two $\mathrm{NMe}_{2}$ units of the aryldiamine ligand and an

(4) Hoffmann, R. Angew. Chem. 1982, 94, 725.

(5) (a) Hart, I. J.; Jeffrey, J. C.; Lowry, R. M.; Stone, F. G. A. Angew. Chem., Int. Ed. Engl. 1988, 27, 1703. (b) Kim, H. P.; Angelici, R. J. Adv. Organomet. Chem. 1987, 27, 51.

(6) (a) Klăui, W.; Hamers, H.; Pfeffer, M.; De Cian, A.; Fischer, J. J. Organomet. Chem. 1990, 394, 213. (b) Engel, P. F.; Pfeffer, M.; Fischer, J.; Dedieu, A. J. Chem. Soc., Chem. Commun. 1991, 1274.

(7) (a) Freudenberger, J. H.; Schrock, R. R. Organometallics 1985, 4, 1937. (b) McCullough, L. G.; Schrock, R. R.; Dewan, J. C.; Murdzek, J. C. J. Am. Chem. Soc. 1985, 107, 5987.

(8) Freudenberger, J. H.; Schrock, R. R. Organometallics 1986, 5, 398. (9) (a) Sharp, P. R.; Astruc, D.; Schrock, R. R. J. Organomet. Chem. 1979, 182, 477. (b) Abbenhuis, H. C. L.; Grove, D. M.; van der Sluis, P.; Spek, A. L.; van Koten, G. Recl. Trav. Chim. Pays-Bas 1990, 109, 446. (c) Abbenhuis, H. C. L.; Feiken, N.; Haarman, H. F.; Grove, D. M.; Horn, E.; Kooijman, H.; Spek, A. L.; van Koten, G. Angew. Chem., Int. Ed. Engl. 1991, 30, 996.

(10) Gal, A. W.; van der Heijden, H. J. Chem. Soc., Chem. Commun. $1983,420$.

(11) Jastrzebski, J. T. B. H.; van Koten, G.; Konijn, M.; Stam, C. H. J. Am. Chem. Soc. 1982, 104, 5490.
AX pattern for each of the two $\mathrm{CH}_{2} \mathrm{~N}$ units. Since there are also four ${ }^{13} \mathrm{C} \mathrm{NMR}$ resonances for the $\mathrm{NMe}_{2}$ units, one can conclude that each nitrogen center is a stable tetrahedral array that reflects the molecular asymmetry present. This can only occur when both pyramidal inversion of the nitrogen center is blocked and when rotation around the $\mathrm{C}-\mathrm{NMe}_{2}$ bond is hindered. This means that in 2 the tantalum-nitrogen and the zinc-nitrogen interactions are stable on the NMR time scale and that in solution it has a structure with stable five-membered $\mathrm{Ta}-\mathrm{C}-\mathrm{C}-\mathrm{C}-\mathrm{N}$ and $\mathrm{Zn}-\mathrm{C}-\mathrm{C}-\mathrm{C}-\mathrm{N}$ chelate rings. The ${ }^{13} \mathrm{C}$ NMR spectrum contains a resonance at $\delta 295.4 \mathrm{ppm}$ for the bridging alkylidyne $\alpha$-carbon. The resonance for the bridging $C_{i p s o}$ atom of the monoanionic aryldiamine ligand is at $\delta \mathbf{1 7 5 . 2}$ and is to a higher field of the nonbridging $\mathrm{C}_{i p s o}$ atom resonances in other aryltantalum complexes ${ }^{9}$ that are found in the range $190 \leq \delta \leq 210$.

Solid State Structure and Molecular Geometry of $\mathrm{TaCl}_{2}\left\{\mathrm{C}_{6} \mathrm{H}_{3}\left(\mathrm{CH}_{2} \mathrm{NMe}_{2}\right)_{2}-2,6\right\}(\mu-\mathrm{C}-t-\mathrm{Bu})(\mu-\mathrm{ZnCl})(2)$. In order to elucidate the stereochemistry of the ligand distribution around the metal centers and to obtain information about the bonding modes of both the aryldiamine ligand and the alkylidyne unit, an X-ray structural analysis of 2 has been carried out. Suitable crystals were grown from a benzene solution of 2 into which pentane vapor was allowed to diffuse slowly. ${ }_{12}^{2}$ The crystal structure of 2 involves the packing of four discrete monomers in an orthorhombic unit cell. An ORTEP drawing of 2, along with the adopted numbering scheme is shown in Figure 1; selected bond lengths and angles are listed in Table I. The structure determination shows 2 to be a bimetallic species in which the metal atoms of a $\mathrm{TaCl}_{2}$ and a $\mathrm{ZnCl}$ unit are bridged by a neopentylidyne ( $\equiv \mathrm{C}-t-\mathrm{Bu})$ unit via carbyne carbon $\mathrm{C}(13)$ and an aryldiamine $\left(\mathrm{C}_{6} \mathrm{H}_{3}\left(\mathrm{CH}_{2}\right.\right.$ $\left.\left.\mathrm{NMe}_{2}\right)_{2}-2,6\right)$ ligand via $\mathrm{C}_{\text {ipso }}$ atom $\mathrm{C}(9)$. The aryldiamine ligand further coordinates through the $\mathrm{N}$-donor atoms of its two $\mathrm{CH}_{2} \mathrm{NMe}_{2}$ arms, one to each metal, to complete the coordination sphere of the two metal centers. The resulting coordination geometry around zinc is distorted tetrahedral and that around tantalum is between trigonal bipyramidal and square pyramidal (70\% along the Berry pseudorotation coordinate toward the latter). ${ }^{13}$ The $\mathrm{C}(9)$ based aryl ligand bridge between zinc and tantalum is very asymmetric: the angle made by the $\mathrm{Ta}-\mathrm{Zn}$ vector with the least squares plane through the aryl carbon atoms is $65.2(2)^{\circ}$ and deviates markedly from the $90^{\circ}$ expected for a symmetrically bridging aryl system (see Figure 2).

$\mathrm{C}-\mathrm{H}$ Bond Activation Reaction of a $\mathrm{NMe}_{2}$ Group in 2. Treatment of bimetallic 2 with one or more equivalents of tmeda $\left[=\mathrm{Me}_{2} \mathrm{~N}\left(\mathrm{CH}_{2}\right)_{2} \mathrm{NMe}_{2}\right]$ at $60^{\circ} \mathrm{C}$ leads

(12) van der Sluis, P.; Hezemans, A. M. F.; Kroon, J. Appl. Crystallogr. $1989,22,340$.

(13) Holmes, R. R. Prog. Inorg. Chem. 1984, 32, 119 and references cited therein. 


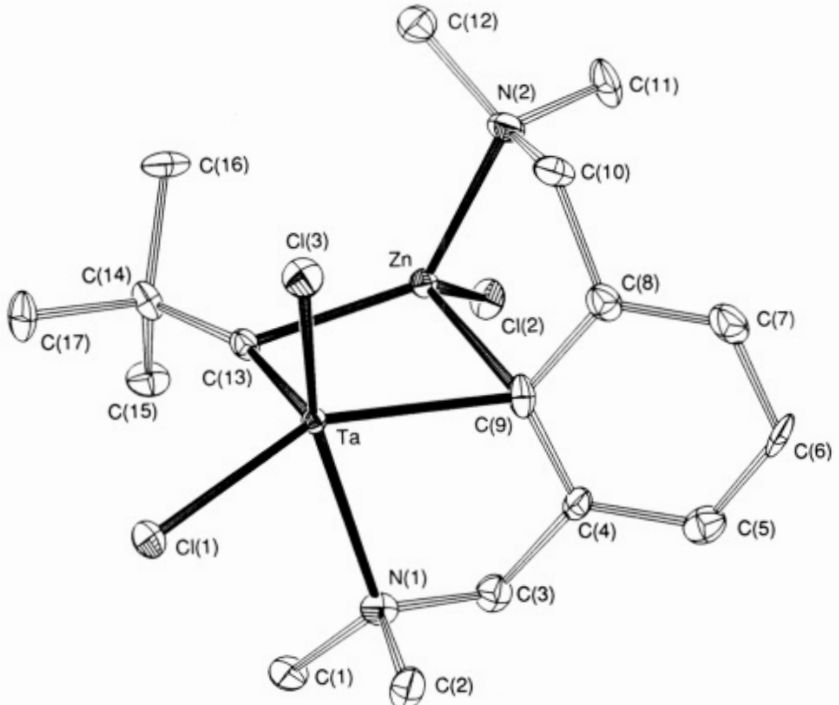

Figure 1. ORTEP drawing of the structure of 2 in the crystal, with $50 \%$ probability ellipsoids.

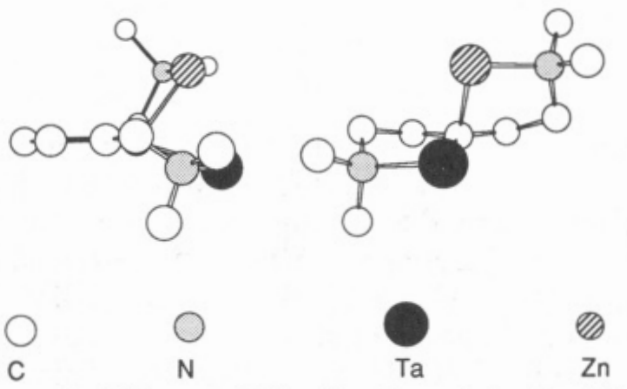

Figure 2. Bridging aryldiamine ligand in the bimetallic complex 2. The other ligands have been omitted for clarity. Left: view along the $\mathrm{C}(4)-\mathrm{C}(8)$ axis (aryl carbon atoms perpendicular to the plane of drawing). Right: approximate view along $\mathrm{Ta}-\mathrm{C}_{i p s o}$.

Table I. Relevant Data for the Geometry of 2

\begin{tabular}{lcll}
\hline \multicolumn{5}{c}{ Bond Lengths $(\AA)$} \\
$\mathrm{Ta}-\mathrm{Cl}(1)$ & $2.3830(15)$ & $\mathrm{Ta}-\mathrm{Cl}(3)$ & $2.3628(16)$ \\
$\mathrm{Ta}-\mathrm{C}(9)$ & $2.321(6)$ & $\mathrm{Ta}-\mathrm{C}(13)$ & $1.862(6)$ \\
$\mathrm{Ta}-\mathrm{N}(1)$ & $2.313(6)$ & $\mathrm{Ta} \cdots \mathrm{Zn}$ & $2.729(1)$ \\
$\mathrm{Zn}-\mathrm{Cl}(2)$ & $2.214(2)$ & $\mathrm{Zn}-\mathrm{C}(9)$ & $2.258(6)$ \\
$\mathrm{Zn}-\mathrm{C}(13)$ & $2.114(6)$ & $\mathrm{Zn}-\mathrm{N}(2)$ & $2.101(5)$ \\
\multicolumn{5}{c}{} \\
$\mathrm{Cl}(1)-\mathrm{Ta}-\mathrm{N}(1)$ & $83.69(15)$ & $\mathrm{N}(1)-\mathrm{Ta}-\mathrm{C}(9)$ & $75.0(2)$ \\
$\mathrm{C}(9)-\mathrm{Ta}-\mathrm{Cl}(3)$ & $95.79(16)$ & $\mathrm{C}(9)-\mathrm{Ta}-\mathrm{C}(13)$ & $102.5(2)$ \\
$\mathrm{Cl}(1)-\mathrm{Ta}-\mathrm{Cl}(3)$ & $91.90(5)$ & $\mathrm{Ta}-\mathrm{C}(13)-\mathrm{C}(14)$ & $158.5(4)$ \\
$\mathrm{Cl}(1)-\mathrm{Ta}-\mathrm{C}(13)$ & $103.04(18)$ & $\mathrm{C}(9)-\mathrm{Zn}-\mathrm{C}(13)$ & $96.9(2)$ \\
$\mathrm{C}(9)-\mathrm{Zn}-\mathrm{Cl}(2)$ & $117.71(17)$ & $\mathrm{C}(9)-\mathrm{Zn}-\mathrm{N}(2)$ & $86.7(2)$ \\
$\mathrm{N}(2)-\mathrm{Zn}-\mathrm{Cl}(2)$ & $108.49(15)$ & $\mathrm{Cl}(2)-\mathrm{Zn}-\mathrm{C}(13)$ & $118.51(15)$
\end{tabular}

to clean and quick elimination of $\mathrm{ZnCl}_{2}$ (as $\mathrm{ZnCl}_{2}$ (tmeda)) with concomitant formation of a tantalum neopentylidene complex 3 characterized as $\mathrm{TaCl} \mathrm{C}_{6} \mathrm{H}_{3}\left(\mathrm{CH}_{2} \mathrm{~N}(\mathrm{Me}) \mathrm{CH}_{2}\right)$ $\left.2-\left(\mathrm{CH}_{2} \mathrm{NMe}_{2}\right)-6\right\}(=\mathrm{CH}-t-\mathrm{Bu})$ (Scheme II, route $\left.i\right)$. The elimination of $\mathrm{ZnCl}_{2}$ from 2 could not be achieved by an analogous reaction with dme or by tetrahydrofuran (THF) at reflux for $4 \mathrm{~h}$. Complex 3 can be regarded as a product that arises from a postulated intermediate $\mathrm{TaCl}\left\{\mathrm{C}_{6} \mathrm{H}_{3}\left(\mathrm{CH}_{2}\right.\right.$ $\left.\left.\mathrm{NMe}_{2}\right)_{2}-2,6\right\}$ ( $\left.\equiv \mathrm{C}-t-\mathrm{Bu}\right)(6)$ by a hydrogen atom abstraction from a methyl group of $a \mathrm{NMe}_{2}$ unit by the $\mathrm{Ta} \equiv \mathrm{C}$ function. In an alternative approach, 3 can be prepared by the reaction of the alkylidene complex 1 with 1 equiv of $\mathrm{MeLi}$ in THF at low temperature (Scheme II, route ii). The remaining chlorine atom of the alkylidene complex 3 can be substituted by a tert-butoxide ligand in a clean transmetalation reaction with $\mathrm{LiO}-t-\mathrm{Bu}$, leading to the halogen-free alkylidene complex $\mathrm{Ta}(0-t-\mathrm{Bu})\left\{\mathrm{C}_{6} \mathrm{H}_{3}\right.$ $\left.\left(\mathrm{CH}_{2} \mathrm{~N}(\mathrm{Me}) \mathrm{CH}_{2}\right)-2-\left(\mathrm{CH}_{2} \mathrm{NMe}_{2}\right)-6\right\}(=\mathrm{CH}-t-\mathrm{Bu})(4)$ in high yield (Scheme II, route $v$ ). The yellow alkylidene complexes 3 and 4 are air-sensitive but thermally quite stable, and they can be stored intact for months under a nitrogen atmosphere.

The ${ }^{1} \mathrm{H}(300.13 \mathrm{MHz})$ and ${ }^{13} \mathrm{C}(75.74 \mathrm{MHz})$ NMR data of 3 and 4 in $\mathrm{C}_{6} \mathrm{D}_{6}$ are consistent with their formulations as shown in Scheme II. As a result of the $\mathrm{C}-\mathrm{H}$ activation reaction (vide supra), they both contain an aryldiamine ligand with one $\mathrm{NMe}_{2}$ and one $\mathrm{NMe}$ unit, and the corresponding three methyl group resonances are observed either at ambient temperature (3) or at lower temperature (4). For complex 4 the two anisochronous ${ }^{1} \mathrm{H}$ NMR resonances for the $\mathrm{NMe}_{2}$ unit coalesce at $20^{\circ} \mathrm{C}$ (toluene$d_{8}$ ). In the ${ }^{1} \mathrm{H}$ NMR spectra of both 3 and 4 the three $\mathrm{CH}_{2}(\mathrm{~N})$ moieties present each provide an $\mathrm{AB}$ pattern. $\mathrm{A}$ high-field AX pattern ( $\delta 3.0$ and 1.3 ) with a small ${ }^{2} J(\mathrm{H}, \mathrm{H})$ of $10 \mathrm{~Hz}$ can be assigned to the new $\mathrm{Ta}-\mathrm{CH}_{2}-\mathrm{N}$ unit that has resulted from the $\mathrm{C}-\mathrm{H}$ activation reaction; the $\mathrm{Ta}-\mathrm{CH}_{2}-\mathrm{N}$ unit in the related, and structurally characterized, complex $\mathrm{TaCl}_{2}\left\{\mathrm{C}_{6} \mathrm{H}_{4}\left(\mathrm{CH}(\mathrm{Me}) \mathrm{N}(\mathrm{Me}) \mathrm{CH}_{2}\right)-2\right\}$ $\left(\mathrm{CH}_{2} \mathrm{Ph}\right)(\mathrm{THF})$ provides similar NMR data. ${ }^{14}$ To gain insight into the bonding in the triangular $\mathrm{Ta}-\mathrm{CH}_{2}-\mathrm{N}$ unit, proton-coupled ${ }^{13} \mathrm{C}$ NMR spectra have been measured for 3 and 4 and these provided ${ }^{1} J(\mathrm{C}, \mathrm{H})$ values of 146 and $141 \mathrm{~Hz}$, respectively; these are close to the ${ }^{1} J(\mathrm{C}, \mathrm{H})$ value of $135 \mathrm{~Hz}$ in the $\mathrm{Ar}-\mathrm{CH}_{2} \mathrm{~N}$ units. The NMR data of the $\mathrm{C}_{\alpha}$ alkylidene atom of the $=\mathrm{CH}-t$-Bu unit in $3(\delta 253.1$, $\left.{ }^{1} J\left(\mathrm{C}_{\alpha}, \mathrm{H}\right)=91 \mathrm{~Hz}\right)$ and in $4\left(\delta 250.3,{ }^{1} J\left(\mathrm{C}_{\alpha}, \mathrm{H}\right)=96 \mathrm{~Hz}\right)$ are typical for electron-deficient alkylidene complexes. ${ }^{15}$

The reactivity of the alkylidene complexes 3 and 4 toward alkenes is very low. In $\mathrm{C}_{6} \mathrm{D}_{6}$ complexes 3 and 4 react slowly with ethene and neopentylethene $(4,4-$ dimethylpent-1-ene) is liberated, but the reaction is not clean; no trace of the metathesis product tert-butylethene (3,3-dimethylbut-1-ene) was detected. The formation of neopentylethene is indicative of a reductive rearrangement occurring in an intermediate tantalacyclobutane complex (as is regularly observed in tantalum alkylidene-mediated reactions ${ }^{16}$ ) and has not been further investigated.

Evidence for a Palladium-Mediated Synthesis of a Functionalized Tantalum Alkylidene Complex. Bimetallic 2 does not react with $\left[\mathrm{Pd}\left(\mathrm{C}_{6} \mathrm{H}_{4} \mathrm{CH}_{2} \mathrm{NMe}_{2}-2\right)(\mu\right.$ $\mathrm{X})]_{2}(\mathrm{X}=\mathrm{Cl}, \mathrm{I})$ in either toluene or THF. When, however, the tmeda-induced elimination of $\mathrm{ZnCl}_{2}$ from bimetallic 2 is performed in the presence of these dimeric palladium complexes the final product isolated in low yield is a blue complex 5 (Scheme II, routes iii and $i v$ ) and not 3 (the product of a $\mathrm{C}-\mathrm{H}$ activation reaction). Complex 5 is airsensitive and slightly thermally unstable but can be stored intact under a nitrogen atmosphere at $-30^{\circ} \mathrm{C}$. For 5 the ${ }^{1} \mathrm{H}$ and ${ }^{13} \mathrm{C}$ NMR data (vide infra) are consistent with a proposed formulation of $\mathrm{TaCl}_{2}\left(\mathrm{C}_{6} \mathrm{H}_{4} \mathrm{CH}_{2} \mathrm{NMe}_{2}-2\right)[=\mathrm{C}(t$ -

(14) Abbenhuis, H. C. L.; Grove, D. M.; van Mier, G. P. M.; Spek, A. L. Recl. Trav. Chim. Pays-Bas 1990, 109, 363. Abbenhuis, H. C. L.; van Belzen, R.; Grove, D. M.; Klomp, A. J. A.; van Mier, G. P. M.; Spek, A. L.; van Koten, G. Organometallics 1993, 12, 210.

(15) (a) Schultz, A. J.; Brown, R. K.; Williams, J. M.; Schrock, R. R. J. Am. Chem. Soc. 1981, 103, 169. (b) Churchill, M. R.; Hollander, F. J. Inorg. Chem. 1978, 17, 1957. (c) Churchill, M. R.; Youngs, W. J. Inorg. Chem. 1979, 18, 1930. (d) Churchill, M. R.; Wasserman, H. J. Inorg. Chem. 1981, 20, 2899. (e) An excellent reference book is: Nugent, W. A.; Mayer, J. M. Metal-Ligand Multiple Bonds; John Wiley \& Sons Ltd.: New York, 1988. (f) Schrock, R. R. In Reactions of Coordinated Ligands; Braterman, P. S., Ed.; Plenum: New York, 1986; Vol. 1.

(16) (a) McLain, S. J.; Wood, C. D.; Schrock, R. R. J. Am. Chem. Soc. 1979, 101, 4558. (b) Schrock, R. R. Science 1983, 219, 13. 
Scheme II. Alkylidyne-Mediated Alkylidene Syntheses

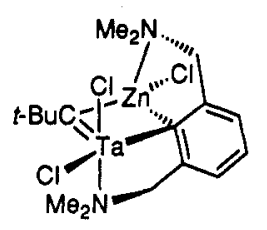

2

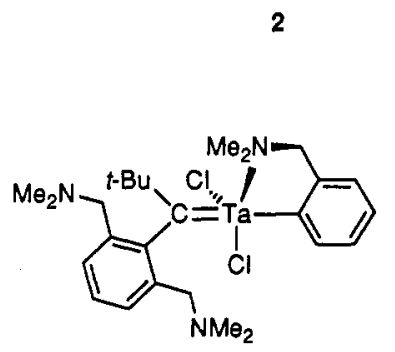

5
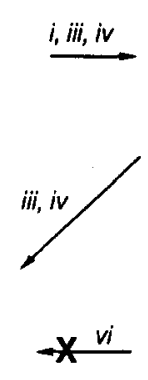

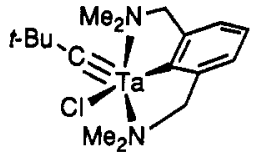

6

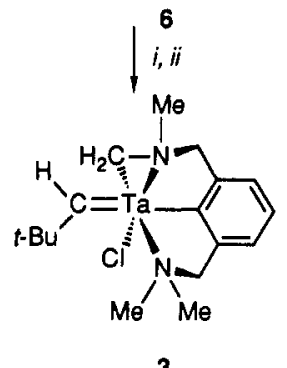

3
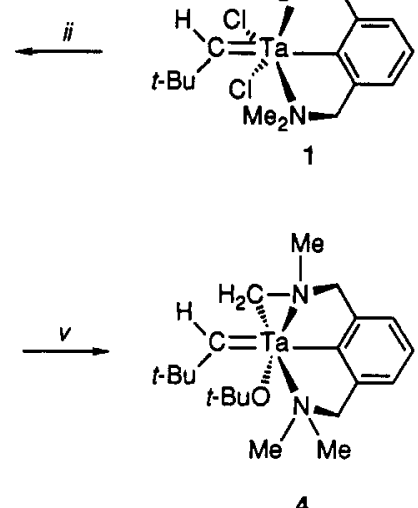

\footnotetext{
i + tmeda (benzene, $60^{\circ} \mathrm{C}$ ) , $-\mathrm{ZnCl}_{2}$ (tmeda), yield $69 \%$.

$i i+\mathrm{LiMe}\left(\mathrm{THF},-78^{\circ} \mathrm{C}\right),-\mathrm{CH}_{4},-\mathrm{LiCl}$, yield $40 \%$.

$i i i+$ tmeda, $+\left[\mathrm{Pd}\left(\mathrm{C}_{6} \mathrm{H}_{4} \mathrm{CH}_{2} \mathrm{NM}_{2}-2\right)(\mu-1)\right]_{2},-\mathrm{ZnCl}(\mathrm{l})($ tmeda $),-\mathrm{Pd}^{0}$, yield $\sim 50 \%$.

$i v+$ tmeda, $+\left[\mathrm{Pd}\left(\mathrm{C}_{6} \mathrm{H}_{4} \mathrm{CH}_{2} \mathrm{NM}_{2}-2\right)(\mu-\mathrm{Cl})\right]_{2},-\mathrm{ZnCl}_{2}$ (tmeda), $-\mathrm{Pd}^{0}$, yield $\sim 20 \%$.

$v+\mathrm{LiO}-\mathrm{t}-\mathrm{Bu},-\mathrm{LiCl}$, yield $100 \%$.

$v i+\left[P d\left(\mathrm{C}_{6} \mathrm{H}_{4} \mathrm{CH}_{2} \mathrm{NMe}_{2}-2\right)(\mu-X)\right]_{2}(X=1, \mathrm{Cl})$ unclean reaction.
}

Bu) $\left.\left\{\mathrm{C}_{6} \mathrm{H}_{3}\left(\mathrm{CH}_{2} \mathrm{NMe}_{2}\right)_{2}-2,6\right\}\right]$. This is a neopentylidene complex in which the alkylidene $\alpha$-hydrogen atom of a $=\mathrm{CH}-t$-Bu unit (present in 1) has been substituted by a $\mathrm{C}_{6} \mathrm{H}_{3}\left(\mathrm{CH}_{2} \mathrm{NMe}_{2}\right)_{2}-2,6$, aryldiamine, group. Note that regardless of the starting palladium complex the only halide present in isolated 5 is chloride (see Discussion). Attempts to obtain crystals of 5 suitable for X-ray analysis failed since the complex invariably crystallized in thin fibers. When bimetallic 2 was reacted with tmeda in the presence of $\mathrm{ClC}_{6} \mathrm{H}_{4} \mathrm{CH}_{2} \mathrm{NMe}_{2}$-2, instead of $\left[\mathrm{Pd}\left(\mathrm{C}_{6} \mathrm{H}_{4} \mathrm{CH}_{2}\right.\right.$ $\left.\left.\mathrm{NMe}_{2}-2\right)(\mu-\mathrm{X})\right]_{2}(\mathrm{X}=\mathrm{Cl}, \mathrm{I})$, no 5 was formed. Under the same conditions as those that resulted in the formation of 5, $\left.\mathrm{TaCl}_{2} \mathrm{C}_{6} \mathrm{H}_{3}\left(\mathrm{CH}_{2} \mathrm{~N}(\mathrm{Me}) \mathrm{CH}_{2}\right)-2-\left(\mathrm{CH}_{2} \mathrm{NMe}_{2}\right)-6\right\}(=\mathrm{CH}-$ $t$ - $\mathrm{Bu})(3)$ also reacts with $\left[\mathrm{PdX}\left(\mathrm{C}_{6} \mathrm{H}_{4} \mathrm{CH}_{2} \mathrm{NMe}_{2}-2\right)\right]_{2}(\mathrm{X}=$ $\mathrm{Cl}, \mathrm{I})$ but this reaction results in a complex mixture of unidentified organometallic species that does not contain 5 (Scheme II, route vi).

Further evidence for our postulated structure of 5 comes from a FAB mass spectrum of the organic products obtained by hydrolysis of complex 5 . This spectrum showed mainly parent ions that could be attributed to the protonated forms of the arylamine $\mathrm{C}_{8} \mathrm{H}_{5} \mathrm{CH}_{2} \mathrm{NMe}_{2}-2$ $(m / e=136.1)$ and the neopentyl-aryldiamine $\mathrm{CH}_{2}(t$ $\mathrm{Bu})\left\{\mathrm{C}_{6} \mathrm{H}_{3}\left(\mathrm{CH}_{2} \mathrm{NMe}_{2}\right)_{2}-2,6\right\}(m / e=263.2)$. After similar deuterolysis, a FAB mass spectrum was obtained with peaks attributable to $\mathrm{C}_{6} \mathrm{H}_{4} \mathrm{DCH}_{2} \mathrm{NMe}_{2}-2$ and $\mathrm{CD}_{2}(t$ $\mathrm{Bu})\left\{\mathrm{C}_{6} \mathrm{H}_{3}\left(\mathrm{CH}_{2} \mathrm{NMe}_{2}\right)_{2}-2,6\right\}$; the incorporation of one and two deuterium atoms, respectively, in these products is consistent with the deuterolysis of a $\mathrm{Ta}-\mathrm{C}$ single bond and $\mathrm{a} \mathrm{T} a=\mathrm{C}$ double bond in complex 5 .

The ${ }^{1} \mathrm{H}$ NMR spectrum of $5\left(300.13 \mathrm{MHz}, \mathrm{C}_{6} \mathrm{D}_{6}, 25^{\circ} \mathrm{C}\right)$ is given in Figure 3 and shows four anisochronous resonances for $\mathrm{N}$-bonded methyl groups in a 1:1:2:2 ratio and three $A B$ patterns for the $\mathrm{CH}_{2} \mathrm{~N}$ units in accord with the formulation $\mathrm{TaCl}_{2}\left(\mathrm{C}_{6} \mathrm{H}_{4} \mathrm{CH}_{2} \mathrm{NMe}_{2}-2\right)[=\mathrm{C}(t-\mathrm{Bu})-$ $\left.\left\{\mathrm{C}_{6} \mathrm{H}_{3}\left(\mathrm{CH}_{2} \mathrm{NMe}_{2}\right)_{2}-2,6\right\}\right]$, as shown in Scheme II. To reach this conclusion, it is necessary to make the reasonable assumptions that on the NMR time scale only the $\mathrm{NMe}_{2}$ unit of the arylmonoamine $\mathrm{C}_{6} \mathrm{H}_{4} \mathrm{CH}_{2} \mathrm{NMe}_{2}-2$ forms a coordinative bond to the tantalum center and that on this time scale the tantalum center is a chiral entity that does not racemize. In order to facilitate the assignments of the ${ }^{1} \mathrm{H}$ and ${ }^{13} \mathrm{C} \mathrm{NMR}$ data of 5 and to probe the mechanism by which it is formed from bimetallic 2 , we have carried out a deuterium labeling experiment. The $d_{3}$ analogue of 2, $\mathrm{TaCl}_{2}\left\{\mathrm{C}_{6} \mathrm{D}_{3}\left(\mathrm{CH}_{2} \mathrm{NMe}_{2}\right)_{2}-2,6\right\}(\mu-\mathrm{C}-t-\mathrm{Bu})(\mu-\mathrm{ZnCl})$, was prepared (see Experimental Section) and reacted with tmeda and $\left[\mathrm{Pd}\left(\mathrm{C}_{6} \mathrm{H}_{4} \mathrm{CH}_{2} \mathrm{NMe}_{2}-2\right)(\mu-\mathrm{I})\right]_{2}$. This reaction gave $\mathrm{TaCl}_{2}\left(\mathrm{C}_{6} \mathrm{H}_{4} \mathrm{CH}_{2} \mathrm{NMe}_{2}-2\right)\left[=\mathrm{C}(t-\mathrm{Bu})\left\{\mathrm{C}_{8} \mathrm{D}_{3}\left(\mathrm{CH}_{2} \mathrm{NM}_{\theta_{2}}\right)_{2}\right.\right.$ $2,6 \mid]$, and no products with deuterium incorporated in another part of the complex were found (see Figure 3). Comparison of the ${ }^{1} \mathrm{H} N M R$ spectra of 5 and its $d_{3}$ analogue allows assignment of all the aromatic resonances present. In this functionalized alkylidene complex 5 the low-field aryl resonance for one proton of the aryldiamine at $\delta 8.36$ is a remarkable feature for which we have no explanation. Inspection of the aryl resonance multiplicities shows that the $\mathrm{C}_{6} \mathrm{H}_{3}\left(\mathrm{CH}_{2} \mathrm{NMe}_{2}\right)_{2}-2,6$ ligand is intact, and this excludes an interpretation based on isomerization to a 2,4-disubstituted aryldiamine ligand, as encountered in late transition metal chemistry. ${ }^{17}$ The ${ }^{13} \mathrm{C}$ NMR resonance of the alkylidene $\alpha$-carbon in 5 is located at $\delta 278$ and that of the $\mathrm{C}_{i p s o}$ atom of $\mathrm{C}_{6} \mathrm{H}_{4} \mathrm{CH}_{2} \mathrm{NMe}_{2}-2$ is at $\delta 203.8$; these values are characteristic for tantalum ary ${ }^{9}$ and tantalum alkylidene ${ }^{15}$ complexes, respectively. Consistent with the postulated formulation of 5 these two resonances appear as singlets in the proton-coupled ${ }^{13} \mathrm{C}$ NMR spectrum.

\section{Discussion}

Synthesis and Structure of Bimetallic 2. Most known tantalum (and some tungsten) alkylidyne complexes contain a Lewis acid, ${ }^{10,18}$ e.g. $\mathrm{Li}^{+}, \mathrm{ZnCl}^{+}, \mathrm{Zn}^{2+}$, or $\mathrm{Al}^{3+}$ that becomes incorporated as a direct result of the preparative method used. The alkylidene $\alpha-\mathrm{H}$ atom of a precursor alkylidene complex has a relatively high acidity that allows its abstraction (as a proton) by a metal alkyl

(17) van der Zeijden, A. A. H.; van Koten, G.; Luijk, R.; Nordemann, R. A.; Spek, A. L. Organometallice 1988, 7, 1549.

(18) (a) Guggenberger, L. J.; Schrock, R. R. J. Am. Chem. Soc. 1975, 97, 2935. (b) Sharp, P. R.; Holmes, S. J.; Schrock, R. R. J. Am. Chem. Soc. $1981,103,965$. 

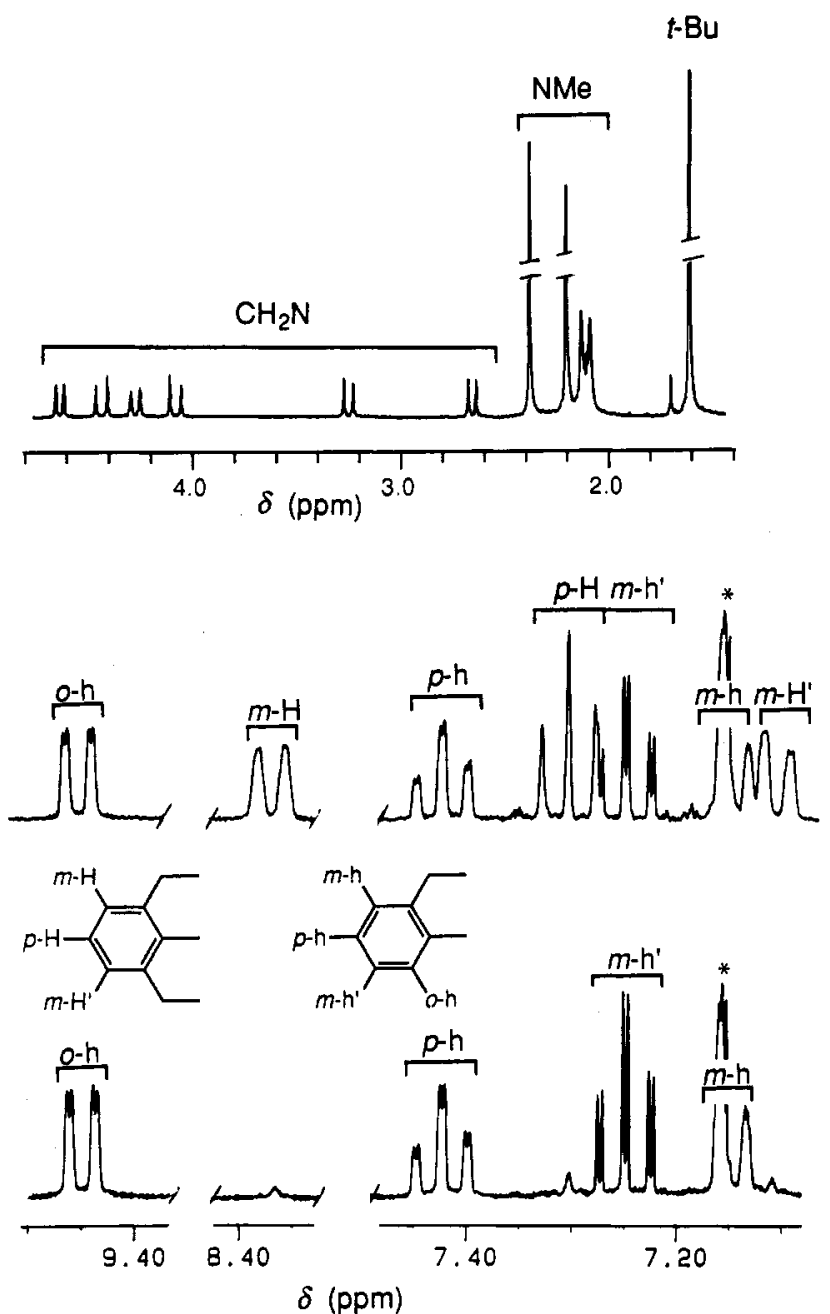

$$
\delta \text { (ppm) }
$$

Figure 3. Top: highfield part of the ${ }^{1} \mathrm{H}$ NMR $\left(\mathrm{C}_{6} \mathrm{D}_{6}, 300.13\right.$ $\mathrm{MHz}$ ) spectrum of the alkylidene complex $\mathrm{TaCl}_{2}\left(\mathrm{C}_{6} \mathrm{H}_{4} \mathrm{CH}_{2-}\right.$ $\left.\mathrm{NMe}_{2}-2\right)\left[=\mathrm{C}(t-\mathrm{Bu})\left\{\mathrm{C}_{6} \mathrm{H}_{3}\left(\mathrm{CH}_{2} \mathrm{NMe}_{2}\right)_{2}-2,6\right\}\right]$ (5). Middle: aromatic resonances of $\mathbf{5}$ and their assignments. Bottom: corresponding resonances in the $d_{3}$ complex containing a $\left\{\mathrm{C}_{6} \mathrm{D}_{3}\left(\mathrm{CH}_{2} \mathrm{NMe}_{2}\right)_{2}-2,6\right\}$ function. (* denotes solvent.)<smiles>C[C](C)C=[Te]</smiles>

a
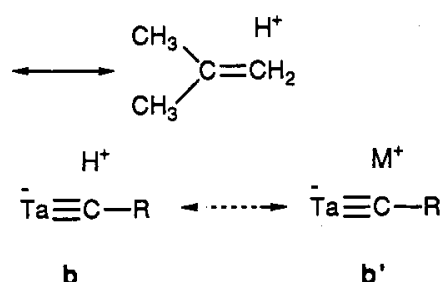

b

Figure 4. Hyperconjugation accounting for the structural features of the tert-butyl cation (top) and by analogy for the structures of the alkylidene complexes (bottom).

compound under mild conditions. This acidity of alkylidene $\alpha-H$ atoms is a feature of high oxidation state, electron-deficient, early transition metal alkylidenes in which the metal withdraws electron density from the alkylidene $\mathrm{C}_{\alpha}-\mathrm{H}_{\alpha}$ bond. This situation using a hyperconjugation description results in a mesomer in which the alkylidene $\alpha$-carbon is triply bonded to the metal center and the alkylidene $\mathrm{C}_{\alpha}-\mathrm{H}_{\alpha}$ bond is weakened (Figure 4 , mesomer b). Similar hyperconjugation is well-known in carbocation chemistry, e.g. the tert-butyl cation (see also Figure 4), and is used to explain short $\mathrm{C}-\mathrm{C}$ bonds and lengthened $\mathrm{C}-\mathrm{H}$ linkages. ${ }^{19}$ Although this model for

(19) Hehre, W. J. Acc. Chem. Res. 1975, 8, 369.
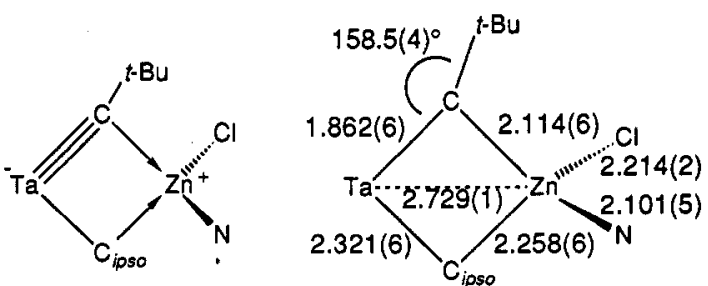

Figure 5. Left: main resonance structure including the coordinative bonds that account for the structural features of bimetallic 2. Right: bond lengths $(\AA)$ in the Ta-C-Zn-C fragment.

describing metal-to-carbon alkylidene bonding has been refined by theoretical studies, ${ }^{20}$ even in this simple form it accounts for all the structural and spectroscopic features of tantalum alkylidene complexes: ${ }^{15}$ (i) the $\mathrm{Ta}-\mathrm{C}_{\alpha}-\mathrm{C}_{\beta}$ angle is typically in the range $150-170^{\circ}$ and is much larger than the $120^{\circ}$ expected for a formally sp ${ }^{2}$-hybridized $\alpha$-carbon; (ii) the $\mathrm{Ta}-\mathrm{C}_{\alpha}-\mathrm{H}_{\alpha}$ angle $\left(70-80^{\circ}\right)$ is small, the $\mathrm{C}_{\alpha}-\mathrm{H}_{\alpha}$ bond $(\sim 1.30 \AA)$ is lengthened, and the value of ${ }^{1} J\left(\mathrm{C}_{\alpha}-\mathrm{H}_{\alpha}\right)$ is small (70-130 Hz); (iii) the $\mathrm{Ta}-\mathrm{C}_{\alpha}$ bond is so short (1.8-2.0 $\AA$ ) that its range overlaps that of the $\mathrm{Ta}-\mathrm{C}_{\alpha}$ bond lengths in tantalum alkylidyne complexes. In 18-electron tantalum alkylidene complexes that do not contain an electrondeficient tantalum center, the resonance structure a (Figure 4) becomes more important and consequently larger $\mathrm{Ta}-\mathrm{C}_{\alpha}$ bond lengths and smaller $\mathrm{Ta}-\mathrm{C}_{\alpha}-\mathrm{C}_{\beta}$ angles are found. ${ }^{21}$ Replacing the proton in resonance structure $\mathrm{b}$ by a metal cation affords an isoelectronic structure $\mathrm{b}^{\prime}$ (Figure 4) that can be used to describe Lewis-acidcontaining alkylidyne complexes; here the hyperconjugative valence structure $b^{\prime}$ is especially important due to the ability of the Lewis acid to bear a significant positive charge.

For bimetallic $\mathrm{TaCl}_{2}\left\{\mathrm{C}_{6} \mathrm{H}_{3}\left(\mathrm{CH}_{2} \mathrm{NMe}_{2}\right)_{2}-2,6\right\}$ ( $\mu$-C- $\left.t-\mathrm{Bu}\right)-$ $(\mu-\mathrm{ZnCl})(2)$ the structural data of the $\mathrm{Ta}(\mu-\mathrm{C}-t-\mathrm{Bu}) \mathrm{Zn}$ unit could be interpreted as a $\mathrm{Ta}=\mathrm{C}-t-\mathrm{Bu}$ fragment combined with a $\mathrm{Zn}-\mathrm{C} \sigma$-bond, i.e. as a zincaalkylidene complex. However, we favor a description with a $\mathrm{Ta} \equiv \mathrm{C}$ $t$-Bu fragment and a $\mathrm{C} \rightarrow \mathrm{Zn}$ donative interaction from a filled p-orbital on $\mathrm{C}_{\alpha}$ (Figure 5), not only because it is in line with the hyperconjugation model but also because it best shows this complex as a precursor to a Lewis-acidfree alkylidyne complex and thus accounts for its observed reactivity. In this description of 2 there are interesting Lewis-base interactions present that lead to an 18-electron count for zinc and to a 14-electron count for tantalum. In detail there are three coordinative bonds to the cationic $\mathrm{ZnCl}^{+}$moiety: the lone pair of one of the nitrogen donors of the aryldiamine ligand, a filled p-orbital of the alkylidyne $\mathrm{C}_{\alpha}$, and a filled p-orbital of the aryldiamine $\mathrm{C}_{i p s o}$ (vide infra). In 2 the bridging interaction of $\mathrm{C}_{i p s o}$ and the orientation of the aryldiamine ring are such that the p-orbital at $\mathrm{C}_{\text {ipso }}$ is directed toward the zinc center while the $\mathrm{Ta}$ atom is almost in line with the $\mathrm{C}_{i p s o}-\mathrm{C}_{\text {para }}$ vector of the aryldiamine ligand (Figure 2). Consequently, the bonding of the bridging $\mathrm{C}_{i p s o}$ is then described as being a 2-electron $\mathrm{Ta}-\mathrm{C}_{i p s o} \sigma$-bond with electron donation of the filled p-orbital of $\mathrm{C}_{i p s o}$ to the zinc center to form a

(20) (a) Goddard, R. J.; Hoffmann, R.; Jemmis, E. D. J. Am. Chem. Soc. 1980, 102, 7667. (b) Franci, M. M.; Pietro, W. J.; Hout, R. F., Jr.; Hehre, W. J. Organometallics 1983, 2, 281. (c) Cundari, T. R.; Gordon, M. S. J. Am. Chem. Soc. 1991, 113, 5231 and references cited therein. (21) (a) Schrock, R. R.; Messerle, L. W.; Clayton, C. D.; Guggenberger, L. J. J. Am. Chem. Soc. 1978, 100, 3793. (b) Guggenberger, L. J.; Schrock, R. R. J. Am. Chem. Soc. 1975, 97, 6579. 
coordinative $\mathrm{Zn}-\mathrm{C}_{i p s o}$ bond. This latter structural feature is like that of the early stages in the attack of an electrophile $\mathrm{E}^{+}$on a benzene ring, i.e. the formation of a $\pi$-complex in which effectively 2-electron donation from the benzene ring to $\mathrm{E}^{+}$occurs.

As in 2 there is also 2-electron donation from an aryl p-orbital to a metal center in the recently reported structure of the arene adduct cis- $\mathrm{Pd}\left(\mathrm{C}_{6} \mathrm{~F}_{5}\right)_{2}\left(\mathrm{C}_{6} \mathrm{H}_{5} \mathrm{CH}_{2}\right.$ $\left.\mathrm{NMe}_{2}\right)^{22}$ This palladium complex and 2 thus mimic an initial stage of electrophilic attack at an aryl carbon atom that does not lead to substantial deformation of the aryl moiety. We have previously reported platinum complexes that contain a $\sigma$-metal-substituted arenonium ion in which rehybridization of an $\mathrm{sp}^{2}-\mathrm{C}$ center has already taken place ${ }^{23}$ and which therefore mimic a later stage in electrophilic attack at an aryl carbon atom.

Spectroscopic evidence for the participation of the $\mathrm{C}_{\text {ipso }}$ p-orbital in bonding to the zinc center is provided by the unusual ${ }^{13} \mathrm{C} N M R \mathrm{C}_{i p s o}$ resonance value of $\delta 175.2$. This value deviates from those found for $\mathrm{C}_{i p s o}$ atoms either in tantalum compounds with the same aryldiamine ligand or in tantalum mesityl compounds $\left(190 \leq \delta \leq 210^{\circ}\right)$ where the low-field resonance arises from aryl-to-tantalum bonding in which there is additional electron donation from the filled p-orbital on $\mathrm{C}_{i p s o}$ to empty d-orbitals on the (electron-deficient) tantalum center. As a result a resonance structure can be drawn in which $\mathrm{C}_{i p s o}$ is doubly bonded to the tantalum, i.e. like the bonding in a tantalum alkylidene fragment, and it is known empirically that the formation of such a carbon-to-metal multiple bond results in a typically low-field carbon resonance of $\delta$ 200-400. In bimetallic 2 the situation is different, the filled p-orbital of $\mathrm{C}_{i p s o}$ is directed toward a zinc center and, thereby, its p-electron density cannot be donated to tantalum so that a high-field shift of $\mathrm{C}_{i p s o}$ results.

This 4-electron three-center $\mathrm{Ta}-\mathrm{C}_{i p s o}-\mathrm{Zn}$ bonding described above is preferred by us over an alternative 2-electron three-center (2e-3c) description. Examples of both types of aryl bonding and borderline cases are welldocumented in arylmagnesium, ${ }^{24}$-copper, and -cuprate chemistry. ${ }^{25-27}$ For instance, in polynuclear arylcopper complexes of the type $\left[\mathrm{Cu}\left(\mathrm{C}_{6} \mathrm{H}_{2} \mathrm{R}_{3}-2,4,6\right)\right]_{4}(\mathrm{R}=\mathrm{Me}, i-\mathrm{Pr}$, $\mathrm{Ph}$ ) an increase in the bulk of the ortho substituents is known to change the nature of the $\mathrm{Cu}-\mathrm{C}_{i p s o}$ bonding from a symmetrical $2 \mathrm{e}-3 \mathrm{c}$ bonding mode in the trimethyl complex, ${ }^{25}$ via asymmetric bonding in the triisopropyl complex (described as either $2 \mathrm{e}-2 \mathrm{c} \mathrm{Cu}-\mathrm{C}_{i p s o}$ bonding and $\mathrm{Cu}-\mathrm{C}_{i p s o} \pi$-donation), ${ }^{26}$ to purely $2 \mathrm{e}-2 \mathrm{c} \mathrm{Cu}-\mathrm{C}_{i p s o}$ bonding in the triphenyl complex. ${ }^{27}$ Overall, the aryldiamine ligand in bimetallic 2 participates in a 4-electron three-center bond involving $\mathrm{C}_{i p s o}$ and in coordinative $\mathrm{Ta}-\mathrm{N}$ and $\mathrm{Zn}-\mathrm{N}$ bonds so that this ligand is an 8-electron donor. Such a high electron donating capacity makes the $\mathrm{C}_{6} \mathrm{H}_{3}\left(\mathrm{CH}_{2}-\right.$ $\left.\mathrm{NMe}_{2}\right)_{2}-2,6$ monoanion an excellent ancillary ligand, that

(22) Falvello, L. R.; Forniós, J.; Navarro, R.; Sicilia, V.; Tomás, M. Angew. Chem., Int. Ed. Engl. 1990, 29, 892.

(23) (a) van Koten, G.; Timmer, K.; Noltes, J. G.; Spek, A. L. J. Chem. Soc., Chem.Commun. 1978, 250. (b) Grove,D.M.; van Koten, G.; Louwen, J. N.; Noltes, J. G.; Spek, A. L.; Ubbels, H. J. C. J. Am. Chem. Soc. 1982, 104, 6609. (c) Terheijden, J.; van Koten, G.; Vinke, I. C.; Spek, A. L. J. Am. Chem. Soc. 1985, 107, 2891.

(24) Markies, P. R.; Schat, G.; Akkerman, O.S.; Bickelhaupt, F.; Smoets, W. J. J.; van der Sluis, P.; Spek, A. L. J. Organomet. Chem. 1990, 393, 315 .

(25) Meyers, E. M.; Gamberotta, S.; Floriani, C.; Chiesi-Villa, A.; Guastini, C. Organometallics 1989, 8, 1067. 211.

(26) Nobel, D.; van Koten, G.; Spek, A. L. Angew. Chem. 1989, 101,

(27) Lingnau, L.; Strähle, J. Angew. Chem. 1988, 100, 409. is capable of stabilizing high oxidation states of early transition metal centers.

Alkylidyne-Mediated C-H Bond Activation in a NMe Unit. The preparation of an alkylidene species $\mathrm{TaCl}\left\{\mathrm{C}_{6} \mathrm{H}_{3}\left(\mathrm{CH}_{2} \mathrm{~N}(\mathrm{Me}) \mathrm{CH}_{2}\right)-2-\left(\mathrm{CH}_{2} \mathrm{NMe}_{2}\right)-6\right\}(=\mathrm{CH}-$ $t$-Bu) (3) both from the bimetallic alkylidyne complex 2 by addition of tmeda and from the neopentylidene complex $\left.\mathrm{TaCl}_{2} \mathrm{C}_{6} \mathrm{H}_{3}\left(\mathrm{CH}_{2} \mathrm{NMe}_{2}\right)_{2}-2,6\right\}$ (=CH- $\left.t-\mathrm{Bu}\right)$ by reaction with $\mathrm{MeLi}$ as base points to the common intermediacy of a very reactive Lewis-acid-free alkylidyne species $\mathrm{TaCl}$ $\left\{\mathrm{C}_{6} \mathrm{H}_{3}\left(\mathrm{CH}_{2} \mathrm{NMe}_{2}\right)_{2}-2,6\right\}(\equiv \mathrm{C}-t-\mathrm{Bu})(6)$. This intermediate arises in the reaction of 2 with tmeda by elimination of $\mathrm{ZnCl}_{2}$ (tmeda) (Scheme II, route $i$ ) and in the reaction of 1 with $\mathrm{MeLi}$ by abstraction of the $\alpha-\mathrm{H}$ atom with formation of $\mathrm{LiCl}$ and $\mathrm{CH}_{4}$ (Scheme II, route ii). In this postulated alkylidyne intermediate 6 there then follows an alkylidynemediated proton abstraction from one of the nitrogenbonded methyl groups of the aryldiamine ligand ( $\mathrm{NMe}$ $\mathrm{C}-\mathrm{H}$ activation) to afford alkylidene species 3 . It has been reported that a similar Lewis-acid-free alkylidyne is probably generated in situ from the reaction of the trimetallic complex $\left\{\mathrm{TaCl}_{2}(\mu-\mathrm{C}-t-\mathrm{Bu})(\mathrm{dme})\right\}_{2} \mathrm{Zn}(\mu-\mathrm{Cl})_{2}$ with alkynes that is accompanied by elimination of $\mathrm{ZnCl}_{2}$ and dme. ${ }^{28}$

On the basis of the substantial, and well-documented, trans influence of a neopentylidyne unit ${ }^{20}$ the intermediate alkylidyne species 6 probably has a square pyramidal structure with the neopentylidyne function in the apical position and the tridentate-bonded aryldiamine ligand and the remaining chlorine atom in the basal plane. In this structure both $\mathrm{NMe}_{2}$ units of the aryldiamine ligand are cis-positioned relative to the neopentylidyne unit and this arrangement is ideal for an alkylidyne-mediated abstraction of a hydrogen atom from a $\mathrm{C}-\mathrm{H}$ bond in a NMe unit; this reaction is likely to occur via a multicenter pathway. Many analogous multicenter $\mathrm{C}-\mathrm{H}$ activation reactions have been documented in the area of high-valent early transition metal chemistry, ${ }^{30}$ and activation by alkyl, alkylidene, and benzyne groups is possible. ${ }^{31}$ For instance, Rothwell and co-workers have shown that the ligands 2,6di-tert-butylphenoxide and 2,6-diphenylphenoxide can undergo intramolecular activation of their aliphatic and aromatic $\mathrm{C}-\mathrm{H}$ bonds at $\mathrm{d}^{0}$ metal centers. ${ }^{32}$ We have already reported a stereoselective $\mathrm{C}-\mathrm{H}$ activation reaction in a NMe unit of the dibenzyltantalum complex $\mathrm{TaCl}_{2}$ $\left\{\mathrm{C}_{6} \mathrm{H}_{4}\left(\mathrm{CH}(\mathrm{Me}) \mathrm{NMe}_{2}\right)-2\right\}\left(\mathrm{CH}_{2} \mathrm{Ph}\right)_{2}$ that occurs via a multicentered $\sigma$-bond metathesis and that leads to the formation of a triangular $\mathrm{Ta}-\mathrm{CH}_{2}-\mathrm{N}$ unit ${ }^{14}$ like that in

(28) van der Heijden, H.; Gal, A. W.; Pasman, P.; Orpen, A. G. Organometallics $1985,4,1847$.

(29) (a) Edwards, D. S. Biondi, L. V. Ziller, J. W. Churchill, M. R. Schrock, R. R. Organometallics 1983, 2, 1505. (b) Rocklage, S.M.; Schrock, R. R.; Churchill, M. R.; Wasserman, H. J. Organometallics 1982, 1, 1332. (c) Chiu, K. W.; Jones, R. A.; Wilkinson, G.; Galas, A. M. R.; Hursthouse, M. B. Malik, K. M. A. J. Chem. Soc., Dalton Trans, 1981, 1204. (d) Chisholm, M. H.; Conroy, B. K.; Huffman, J. C. Organometallics 1986, 5, 2384 . (e) Mayr, A.; Dorries, A. M.; McDermott, G. A.; Geib, S. J.; Rheingold, A. L. J. Am. Chem. Soc. 1985, 107, 7775. (f) Fischer, E. O. Wittmann, D.; Himmelreich, D.; Cai, R.; Ackermann, K.; Neugebauer, D. Chem. Ber. 1982, 115, 3152.

(30) Ryabov, A. D. Chem. Rev. 1990, 90, 403.

(31) (a) Latesky, S. L.; McMullen, A. K.; Rothwell, I. P.; Huffman, J. C. J. Am. Chem. Soc. 1985, 107, 5981. (b) Chamberlain, L. R.; Rothwell, I.P.; Huffman, J.C. J. Am. Chem. Soc. 1986, 108, 1629. (c) Chamberlain, L. R.; Kerschner, J. L.; Rothwell, A. P.; Rothwell, I. P.; Huffman, J. C. J. Am. Chem. Soc. 1987, 109, 6471. (d) Chamberlain, L. R.; Rothwell, I. P. J. Am. Chem. Soc. 1983, 105, 1665.

(32) Rothwell, I. P. Acc. Chem. Res. 1988, 21, 153. 
Scheme III. Reported Reactivity of Low-Valent Carbene Complexes with Cyclometalated Palladium Compounds

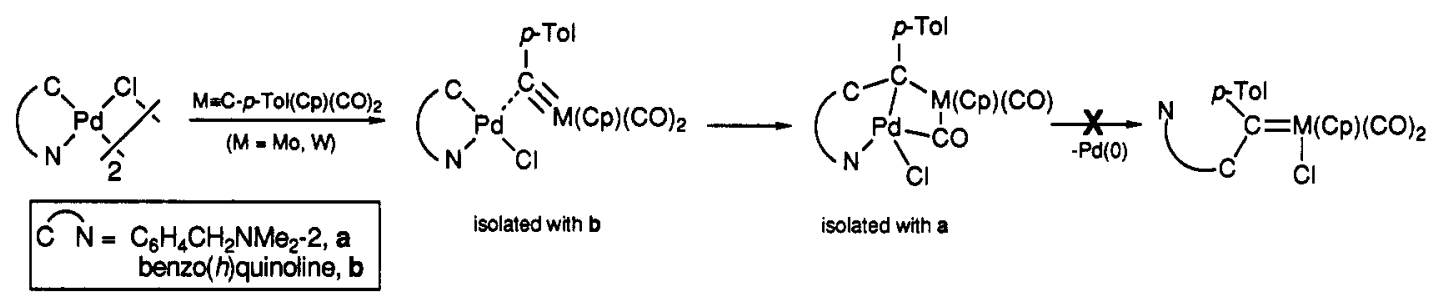

3 and 4. ${ }^{14}$ Structurally similar triangular $\mathrm{Ta}-\mathrm{CH}_{2}-\mathrm{P}$ and $\mathrm{Ta}=\mathrm{CH}-\mathrm{P}$ units have also been reported. ${ }^{33}$

The formation of the functionalized alkylidene complex $\mathrm{TaCl}_{2}\left(\mathrm{C}_{6} \mathrm{H}_{4} \mathrm{CH}_{2} \mathrm{NMe}_{2}-2\right)\left[=\mathrm{C}\left(t-\mathrm{Bu}_{2}\right) \mathrm{C}_{6} \mathrm{H}_{3}\left(\mathrm{CH}_{2} \mathrm{NMe}_{2}\right)_{2}-\right.$ $2,6\}](5)$ from 2 with tmeda and $\left[\mathrm{Pd}\left(\mathrm{C}_{6} \mathrm{H}_{4} \mathrm{CH}_{2} \mathrm{NMe}_{2}-2\right)-\right.$ $(\mu-\mathrm{X})]_{2}$ can also be explained by assuming 6 to be a key intermediate. However, details of this route are far from clear and the absence of the diiodo or iodo/chloro analogue of 5 clearly indicates that halogen exchange processes are important and that $\mathrm{ZnXCl}$ species invariably provide one of the chlorine atoms present in 5; in combination with the long reaction times employed and the heterogeneous nature of the reaction medium it is not inconsistent that the better yield of dichloro complex 5 was obtained with $\left[\mathrm{Pd}\left(\mathrm{C}_{6} \mathrm{H}_{4} \mathrm{CH}_{2} \mathrm{NMe}_{2}-2\right)(\mu-\mathrm{I})\right]_{2}$ as starting material. Complex 5 can be thought of as arising from insertion of the alkylidyne unit of 6 into the $\mathrm{Ta}-\mathrm{C}_{i p s o}$ bond of the aryldiamine, formally a reductive elimination reaction. Complementary to this reductive step, the $\mathrm{C}_{6} \mathrm{H}_{4} \mathrm{CH}_{2}$ $\mathrm{NMe}_{2}-2$ grouping and a chlorine atom are transferred to the tantalum center in an oxidative fashion, formally an oxidative addition of an aryl chloride to a tantalum(III) center. However, the mechanism and exact role played by the palladium center in the overall formation of 5 are not fully understood; among unsolved points are the incorporation of two $\mathrm{Cl}$ atoms in the product even when $\left[\operatorname{Pd}\left(\mathrm{C}_{6} \mathrm{H}_{4} \mathrm{CH}_{2} \mathrm{NMe}_{2}-2\right)(\mu-\mathrm{I})\right]_{2}$ is used and the fact that simple reaction of the aryl chloride $\mathrm{ClC}_{6} \mathrm{H}_{4} \mathrm{CH}_{2} \mathrm{NMe}_{2}-2$ with 2 in the presence of tmeda does not afford 5 at all.

Nevertheless, the conversion of 2 to 5 is a new example illustrating the potential of palladium-mediated functionalization of an alkylidyne complex. Among other examples are the recently reported reactions of low-valent carbyne complexes $\mathrm{M} \equiv \mathrm{C}$ - $\mathrm{p}$ - $\mathrm{Tol}(\mathrm{Cp})(\mathrm{CO})_{2}(\mathrm{M}=\mathrm{Mo}, \mathrm{W})$ with cyclometalated palladium compounds (Scheme III) ${ }^{6 \mathrm{~b}}$ that afford heterobimetallic species which are either adducts of the palladium moiety to a metal carbyne or products resulting from insertion of the $\mathrm{M} \equiv \mathrm{C}$ triple bond into a $\mathrm{Pd}-\mathrm{C}$ bond. Reductive elimination from the latter would result in complexes containing functionalized alkylidene units as in 5 , but this has so far not be achieved (possibly due to the stabilizing influence of the CO ligands).

\section{Conclusions}

The synthetically easily accessible bimetallic tantalumzinc complex 2 is an excellent precursor for a very reactive alkylidyne species and provides insight into the versatility of aryl-to-metal bonding. The ancillary $\mathrm{C}_{6} \mathrm{H}_{3}\left(\mathrm{CH}_{2} \mathrm{NMe}_{2}\right)_{2}-$ 2,6 aryldiamine ligand in 2 acts as an unanticipated 8-electron donor with a demonstrated ability to stabilize

(33) (a) Cotton, F. A.; Falvello, L. R.; Najjar, R. C. Organometallics 1980, 1, 1640. (b) Gibson, V. C.; Graimann, C. E.; Hare, P. M.; Green M. L. H.; Bandy, J. A.; Grebenik, P. D.; Prout, K. J. Chem. Soc., Dalton Trans. 1986, 2025. "state of the art" early transition metal species. Under specific conditions, this aryldiamine can act as a proton donor by converting one of its $\mathrm{NMe}_{2}$ units into a new anionic N,C-chelating fragment: $\mathrm{N}(\mathrm{Me}) \mathrm{CH}_{2}-$. Starting from bimetallic 2, a completely new method for functionalized alkylidenes seems to be possible.

\section{Experimental Section}

All experiments were performed in a dry nitrogen atmosphere using standard Schlenk techniques. Solvents were stored over sodium benzophenone ketyl and distilled prior to use. Elemental analyses were provided by the Institute of Applied Chemistry (TNO), Zeist, or by Dornis and Kolbe, Mülheim a.d. Ruhr; ${ }^{1} \mathrm{H}$ and ${ }^{13} \mathrm{C}$ NMR spectra were recorded on Bruker AC200 or AC300 spectrometers. Mass spectra for the hydrolysis/deuterolysis products of 5 were obtained from $\mathrm{C}_{6} \mathrm{D}_{6} /$ pryridine- $d_{6}$ solutions on a VG Analytical ZAB HF mass spectrometer using FAB ionization with thioglycerol as matrix. $\mathrm{TaCl}_{2}\left\{\mathrm{C}_{6} \mathrm{H}_{8}\left(\mathrm{CH}_{2} \mathrm{NMe}_{2}\right)_{2}-2,6\right\}(=\mathrm{CH}$ $t$-Bu) was prepared according to a literature procedure. ${ }^{9 b}$

$\mathrm{TaCl}_{2}\left\{\mathrm{C}_{4} \mathrm{H}_{3}\left(\mathrm{CH}_{2} \mathrm{NM}_{e_{2}}\right)_{2}-2,6\right\}(\mu-\mathrm{C}-t-\mathrm{Bu})(\mu-\mathrm{ZnCl})(2)$. A purple suspension of $\mathrm{TaCl}_{2}\left\{\mathrm{C}_{6} \mathrm{H}_{3}\left(\mathrm{CH}_{2} \mathrm{NMe}_{2}\right)_{2}-2,6\right\}$ ( $\left.=\mathrm{CH}-t-\mathrm{Bu}\right)(6.31$ $\mathrm{g}, 12.3 \mathrm{mmol})$ in a solution of $\mathrm{ZnCl}_{2}(0.97 \mathrm{~g}, 7.12 \mathrm{mmol})$ and $\mathrm{Zn}\left(\mathrm{CH}_{2}-\mathrm{t}-\mathrm{Bu}\right)_{2}(1.28 \mathrm{~g}, 6.16 \mathrm{mmol})$ in $\mathrm{Et}_{2} \mathrm{O}(100 \mathrm{~mL})$ was stirred at $20^{\circ} \mathrm{C}$ for 5 days. The solvent was removed in vacuo and the sticky residue triturated with hexane. The resulting red powder was extracted with warm $\left(50^{\circ} \mathrm{C}\right)$ benzene $(150 \mathrm{~mL})$. The extract was concentrated in vacuo to $c a .50 \mathrm{~mL}$ and layered with pentane $(200 \mathrm{~mL})$. After standing at $20^{\circ} \mathrm{C}$ for 3 days, large red crystals of the product could be isolated; yield: $5.94 \mathrm{~g}(79 \%)$. Anal. Calcd for $\mathrm{C}_{17} \mathrm{H}_{28} \mathrm{~N}_{2} \mathrm{Cl}_{3} \mathrm{TaZn}: \mathrm{C}, 33.30 ; \mathrm{H}, 4.60 ; \mathrm{N}, 4.57$. Found: $\mathrm{C}, 32.81$; $\mathrm{H}, 4.82 ; \mathrm{N}, 4.42$. ${ }^{1} \mathrm{H}$ NMR (200.13 MHz, $\left.\mathrm{C}_{6} \mathrm{D}_{6}, 25^{\circ} \mathrm{C}, \mathrm{TMS}\right): \delta$ $1.55(\mathrm{~s}, 9 \mathrm{H}, t-\mathrm{Bu}), 1.75,1.94,2.42$, and $2.71\left(\mathrm{~s}, 4 \times 3 \mathrm{H}, \mathrm{NCH}_{8}\right)$, $2.26,2.33,4.43$, and $5.03\left[\mathrm{~d}, 2 \mathrm{~J}(\mathrm{H}, \mathrm{H})=13 \mathrm{~Hz}, 4 \times 1 \mathrm{H}, \mathrm{CH}_{2} \mathrm{~N}\right.$ ], 6.62 (dd, $\left.2 \mathrm{H}, m-\mathrm{C}_{6} \mathrm{H}_{3}\right), 6.97\left(t, 1 \mathrm{H}, p-\mathrm{C}_{6} \mathrm{H}_{3}\right) .{ }^{18} \mathrm{C}\left\{{ }^{1} \mathrm{H}\right\} \mathrm{NMR}$ (50.32 MHz, $\left.\mathrm{C}_{6} \mathrm{D}_{6}, 25^{\circ} \mathrm{C}, \mathrm{TMS}\right): \delta 35.2\left[\mathrm{C}\left(\mathrm{CH}_{3}\right)_{3}\right], 51.2\left[\mathrm{C}\left(\mathrm{CH}_{3}\right)_{3}\right]$, $47.4,47.9,48.1$, and $54.0\left(\mathrm{NCH}_{3}\right), 67.0$ and $71.6\left(\mathrm{CH}_{2} \mathrm{~N}\right), 175.2$ $\left(\mathrm{C}_{\text {ip poo }}\right.$ of $\left.\mathrm{C}_{6} \mathrm{H}_{3}\right), 295.4$ (C-t-Bu).

$\mathrm{TaCl}_{2} \mathrm{C}_{8} \mathrm{H}_{8}\left(\mathrm{CH}_{2} \mathrm{~N}\left(\mathrm{Me}_{\mathrm{CH}}\right)-2-\left(\mathrm{CH}_{2} \mathrm{NMe}_{2}\right)-6\right\}(=\mathrm{CH}-t-\mathrm{Bu})$ (3). Routej. To astirred purple solution of $\mathrm{TaCl}_{2}\left(\mathrm{C}_{6} \mathrm{H}_{3}\left(\mathrm{CH}_{2} \mathrm{NMe}_{2}\right)_{2-}\right.$ $2,6\}(\mu-\mathrm{C}-t-\mathrm{Bu})(\mu-\mathrm{ZnCl})(0.65 \mathrm{~g}, 1.1 \mathrm{mmol})$ in benzene $(100 \mathrm{~mL})$ at $62{ }^{\circ} \mathrm{C}$ was added tmeda $(1.7 \mathrm{~mL}, 7.4 \mathrm{mmol})$. Within $30 \mathrm{~min}$ at $62^{\circ} \mathrm{C}$, the color of the mixture changed to yellow-brown. After stirring for $18 \mathrm{~h}$ at room temperature, the solvent was removed in vacuo leaving a brown spongy material that was extracted with hexane $(1 \times 100 \mathrm{~mL})$. The solvent was removed from the extract in vacuo, leaving $0.48 \mathrm{~g}(92 \%)$ of crude brown product. Subsequent crystallization from warm $\left(60^{\circ} \mathrm{C}\right)$ hexane $(50 \mathrm{~mL})$ gave $0.35 \mathrm{~g}(69 \%)$ of 3 as large block-shaped yellow crystals.

Route ii. To a stirred purple solution of $\mathrm{TaCl}_{2}\left\{\mathrm{C}_{6} \mathrm{H}_{3}\left(\mathrm{CH}_{2}\right.\right.$ $\left.\left.\mathrm{NMe}_{2}\right)_{2}-2,6\right\}(=\mathrm{CH}-t-\mathrm{Bu})(0.71 \mathrm{~g}, 1.4 \mathrm{mmol})$ in THF $(100 \mathrm{~mL})$ at $-108^{\circ} \mathrm{C}$ was added $0.9 \mathrm{~mL}$ of a $1.6 \mathrm{M}$ solution of LiMe in hexane (1.4 mmol). The resulting solution was allowed to warm to room temperature during which time the color gradually changed to brown-red. The solvent was removed in vacuo affording a solid that was suspended in hexane $(100 \mathrm{~mL})$ and stirred for 2 days. Subsequent hot filtration $\left(60^{\circ} \mathrm{C}\right)$ gave an orange filtrate that was concentrated in vacuo to ca. $40 \mathrm{~mL}$. From this concentrated solution, yellow 3 crystallized readily at $-30^{\circ} \mathrm{C}$; yield $0.26 \mathrm{~g}(40 \%)$. 
Table II. Crystal Data and Details of the Structure Determination of 2

$\begin{array}{lc} & \text { (a) Crystal Data } \\ \text { formula } & \mathrm{C}_{17} \mathrm{H}_{28} \mathrm{Cl}_{3} \mathrm{~N}_{2} \mathrm{TaZn} \\ \text { mol wt } & 613.11 \\ \text { cryst syst } & \text { orthorhombic } \\ \text { space group } & P 2_{1} 2_{1} 2_{1}(\mathrm{No} .19) \\ a, b, c(\AA) & 9.725(2), 10.436(2), 20.766(3) \\ V\left(\AA^{3}\right) & 2107.5(7) \\ Z & 4 \\ D_{\text {calc }}\left(\mathrm{g} \mathrm{cm}^{-3}\right) & 1.932(1) \\ F(000) & 1192 \\ \mu\left(\mathrm{cm}^{-1}\right) & 66.8 \\ \text { cryst size (mm) } & 0.37 \times 0.63 \times 0.80 \\ & \text { (b) Data Collection } \\ \text { temp }(\mathrm{K}) & 100 \\ \theta_{\min , \theta_{\max }} & 1.0,29.4 \\ \text { scan type } & \omega / 2 \theta \\ \text { radiation, } \lambda(\AA) & \text { Mo K } \alpha, 0.71073 \\ \Delta \omega(\text { deg) } & 0.81+0.35 \text { tan } \theta \\ \text { hor and vert aperture (mm) } & 2.83,5.0 \\ \text { ref reflns } & -4,4,0 ; 4,0,-4 ; 0,4,-4 \\ \text { data set } & -12 \text { to }+13,0-14,-24 \text { to } 0 \\ \text { total no of data, no. of unique data } & 5481,4851 \\ \text { no. of obsd data } & 4746[I>2.5 \sigma(I)] \\ & \text { (c) Refinement } \\ N_{\text {ref, }} N_{\text {per }} & 4746,219 \\ \text { weighting scheme } & w=1.0 /\left[\sigma^{2}(F)+0.0017 F^{2}\right] \\ \text { final } R, R_{w,} S & 0.034,0.054,2.69 \\ \text { max/av shift/error } & 0.09 / 0.01 \\ \left.\text { min } / \text { max resd dens (e/ } / \AA^{3}\right) & -1.8 / 1.6(\text { near heavy atoms) } \\ & \end{array}$

Anal. Calcd for $\mathrm{C}_{17} \mathrm{H}_{28} \mathrm{~N}_{2} \mathrm{ClTa}$ C, 42.82; $\mathrm{H}, 5.92 ; \mathrm{N}, 5.88$. Found: C, 42.75; H, 5.94; N, 5.81. ${ }^{1} \mathrm{H}$ NMR (300.13 MHz, $\mathrm{C}_{6} \mathrm{D}_{6}$, $\left.24^{\circ} \mathrm{C}, \mathrm{TMS}\right): \delta 0.90(\mathrm{~s}, 1 \mathrm{H}, \mathrm{CH}-t-\mathrm{Bu}), 1.17$ (s, $\left.9 \mathrm{H}, \mathrm{CH}-t-B u\right)$, 1.32 and $3.18\left[2 \mathrm{~d},{ }^{2} J(\mathrm{HH})=9.6 \mathrm{~Hz}, 2 \times 1 \mathrm{H}, \mathrm{TaCH}_{2} \mathrm{~N}\right], 2.07$, 2.85, and $2.97\left[3 \mathrm{~s}, 3 \times 3 \mathrm{H}, \mathrm{N}\left(\mathrm{CH}_{3}\right)\right], 3.20$ and $4.09\left[2 \mathrm{~d},{ }^{2} J(\mathrm{HH})\right.$ $\left.=15.7 \mathrm{~Hz}, 2 \times 1 \mathrm{H}, \mathrm{CH}_{2} \mathrm{~N}\right], 3.32$ and $4.47\left[2 \mathrm{~d},{ }^{2} J(\mathrm{HH})=12.9\right.$ $\left.\mathrm{Hz}, 2 \times 1 \mathrm{H}, \mathrm{CH}_{2} \mathrm{~N}\right], 6.98$ (dd, $\left.2 \mathrm{H}, m-\mathrm{C}_{6} \mathrm{H}_{3}\right), 7.14\left(\mathrm{t}, 1 \mathrm{H}, p-\mathrm{C}_{6} \mathrm{H}_{3}\right.$ ). ${ }^{13} \mathrm{C}\left\{{ }^{1} \mathrm{H}\right\}$ NMR (50.32 MHz, $\mathrm{C}_{6} \mathrm{D}_{6}, 24^{\circ} \mathrm{C}$, TMS): $\delta 34.4[\mathrm{C}(\mathrm{H}) \mathrm{C}-$ $\left.\left(\mathrm{CH}_{3}\right)_{3}\right], 46.3\left[\mathrm{C}(\mathrm{H}) \mathrm{C}\left(\mathrm{CH}_{3}\right)_{3}\right], 46.9,52.2$, and $58.6\left[\mathrm{~N}\left(\mathrm{CH}_{3}\right)\right], 73.3$ $\left(\mathrm{CH}_{2} \mathrm{~N}\right), 84.5\left(\mathrm{Ta}-\mathrm{CH}_{2} \mathrm{~N}\right), 193.1\left(\mathrm{C}_{i p s o}\right.$ of $\left.\mathrm{C}_{8} \mathrm{H}_{3}\right), 253.1[\mathrm{C}(\mathrm{H})-$ $\left.t-\mathrm{Bu},{ }^{1} J\left({ }^{13} \mathrm{C}-1 \mathrm{H}\right)=91 \mathrm{~Hz}\right]$.

$\mathrm{Ta}(\mathrm{O}-t-\mathrm{Bu})\left\{\mathrm{C}_{6} \mathrm{H}_{3}\left(\mathrm{CH}_{2} \mathrm{~N}(\mathrm{Me}) \mathrm{CH}_{2}\right)-2-\left(\mathrm{CH}_{2} \mathrm{NMe}_{2}\right)-6\right\}(=\mathrm{CH}$ $t-\mathrm{Bu})(4)$. A yellow solution of $3(1.27 \mathrm{~g}, 2.66 \mathrm{mmol})$ and $\mathrm{LiO}$ $t$-Bu $(0.22 \mathrm{~g}, 2.7 \mathrm{mmol})$ in hexane $(100 \mathrm{~mL})$ was stirred for $2 \mathrm{~h}$ at $40^{\circ} \mathrm{C}$ and then for $3 \mathrm{~h}$ at $20^{\circ} \mathrm{C}$. The $\mathrm{LiCl}$ precipitate that formed was filtered off and the solvent removed from the filtrate in vacuo, leaving crude yellow product 4 in quantitative yield. The compound can be purified by recrystallization from a minimum of hexane. Anal. Calcd for $\mathrm{C}_{21} \mathrm{H}_{37} \mathrm{~N}_{2} \mathrm{OTa}$ : $\mathrm{C}, 49.03$; $\mathrm{H}, 7.25 ; \mathrm{N}, 5.44$. Found: C, 48.29; $\mathrm{H}, 7.20 ; \mathrm{N}, 5.36$. ${ }^{1} \mathrm{H}$ NMR (300.13 MHz, $\mathrm{C}_{6} \mathrm{D}_{6}, 24^{\circ} \mathrm{C}$, TMS): $\delta 1.29$ (s, $\left.9 \mathrm{H}, \mathrm{CH}-t-B u\right), 1.41$ $(\mathrm{s}, 9 \mathrm{H}, 0-t-\mathrm{Bu}), 1.37$ and $2.91\left[2 \mathrm{~d},{ }^{2} J(\mathrm{HH})=9.8 \mathrm{~Hz}, 2 \times 1 \mathrm{H}\right.$, $\mathrm{TaCH}_{2} \mathrm{~N}$ ], $2.4\left[\mathrm{br} \mathrm{s}, 6 \mathrm{H}, \mathrm{N}\left(\mathrm{CH}_{3}\right)_{2}\right.$ ] $, 3.03\left(\mathrm{~s}, 3 \mathrm{H}, \mathrm{NCH}_{3}\right), 3.35(\mathrm{~s}$, $1 \mathrm{H}, \mathrm{CH}-t-\mathrm{Bu}), 3.47$ and $4.02[2 \mathrm{~d}, 2 J(\mathrm{HH})=13.0 \mathrm{~Hz}, 2 \times 1 \mathrm{H}$, $\left.\mathrm{CH}_{2} \mathrm{~N}\right], 3.57$ and $4.18\left[2 \mathrm{~d},{ }^{2} \mathrm{~J}(\mathrm{HH})=15.7 \mathrm{~Hz}, 2 \times 1 \mathrm{H}, \mathrm{CH}_{2} \mathrm{~N}\right]$ $7.02\left(\mathrm{~d}, 2 \mathrm{H}, m-\mathrm{C}_{6} \mathrm{H}_{3}\right), 7.18\left(\mathrm{t}, 1 \mathrm{H}, p-\mathrm{C}_{8} \mathrm{H}_{3}\right) .{ }^{13} \mathrm{C}\left\{{ }^{1} \mathrm{H}\right\} \mathrm{NMR}(75.47$ $\left.\mathrm{MHz}, \mathrm{C}_{6} \mathrm{D}_{6}, 24^{\circ} \mathrm{C}, \mathrm{TMS}\right): 834.0\left[\mathrm{C}(\mathrm{H}) \mathrm{C}\left(\mathrm{CH}_{3}\right)_{3}\right], 35.2\left[\mathrm{OC}\left(\mathrm{CH}_{8}\right)_{3}\right]$, $45.2\left[\mathrm{C}(\mathrm{H}) \mathrm{C}\left(\mathrm{CH}_{8}\right)_{3}\right], 47.7(\mathrm{br}), 51.1(\mathrm{br})$, and $58.4\left[\mathrm{~N}\left(\mathrm{CH}_{3}\right)\right], 70.0$ and $73.6\left(\mathrm{CH}_{2} \mathrm{~N}\right), 76.6\left(\mathrm{Ta}-\mathrm{CH}_{2} \mathrm{~N}\right), 77.4\left[\mathrm{OC}\left(\mathrm{CH}_{3}\right)_{3}\right], 194.8\left(\mathrm{C}_{i p s o}\right.$ of $\left.\mathrm{C}_{6} \mathrm{H}_{3}\right), 250.3\left[C(\mathrm{H})-t-\mathrm{Bu},{ }^{1} J\left({ }^{18} \mathrm{C}-1 \mathrm{H}\right)=96 \mathrm{~Hz}\right.$.

$\mathrm{TaCl}_{2}\left(\mathrm{C}_{6} \mathrm{H}_{4} \mathrm{CH}_{2} \mathrm{NMe}_{2}-2\right)\left[=\mathrm{C}(t-\mathrm{Bu})\left\{\mathrm{C}_{6} \mathrm{H}_{3}\left(\mathrm{CH}_{2} \mathrm{NMe}_{2}\right)_{2}-\right.\right.$ 2,6\}] (5). $\left[\mathrm{Pd}\left(\mathrm{C}_{6} \mathrm{H}_{4} \mathrm{CH}_{2} \mathrm{NMe}_{2}-2\right)(\mu-\mathrm{I})\right]_{2}(0.86 \mathrm{~g}, 2.3 \mathrm{mmol})$ was suspended in a stirred solution of $\mathrm{TaCl}_{2}\left\{\mathrm{C}_{6} \mathrm{H}_{3}\left(\mathrm{CH}_{2} \mathrm{NMe}_{2}\right)_{2}-2,6\right\}-$ $(\mu-\mathrm{C}-t-\mathrm{Bu})(\mu-\mathrm{ZnCl})(1.16 \mathrm{~g}, 1.89 \mathrm{mmol})$ in THF (35 mL). A slight excess of tmeda $(0.40 \mathrm{~mL}, 2.65 \mathrm{mmol})$ was added, and the stirred brown suspension gradually blackened during $15 \mathrm{~h}$. The solvent was removed in vacuo and the remaining sticky solid triturated with hexane. Subsequent extraction with hexane $(2 \times 75 \mathrm{~mL})$ followed by removal of the solvent in vacuo gave the crude bluepurple product in $\mathrm{ca} .50 \%$ yield. Compound 5 can be obtained spectroscopically pure (by ${ }^{1} \mathrm{H}$ and ${ }^{13} \mathrm{C}$ NMR) after repeated recrystallization from pentane. Anal. Calcd for $\mathrm{C}_{28} \mathrm{H}_{38} \mathrm{~N}_{3} \mathrm{Cl}_{2} \mathrm{Ta}$ :
Table III. Final Coordinates and Equivalent Isotropic Thermal Parameters and Their Esd's in Parentheses for the Non-H Atoms of 2

\begin{tabular}{lcccc}
\hline atom & $x$ & $y$ & $z$ & $U(\mathrm{eq})^{a}\left(\AA^{2}\right)$ \\
\hline $\mathrm{Ta}$ & $0.25757(2)$ & $0.09897(2)$ & $0.10272(1)$ & $0.0080(1)$ \\
$\mathrm{Zn}$ & $0.07764(6)$ & $-0.08956(6)$ & $0.13719(3)$ & $0.0101(2)$ \\
$\mathrm{Cl}(1)$ & $0.47610(14)$ & $0.20202(14)$ & $0.10627(7)$ & $0.0169(4)$ \\
$\mathrm{Cl}(2)$ & $0.05270(15)$ & $-0.30019(13)$ & $0.13180(7)$ & $0.0152(4)$ \\
$\mathrm{Cl}(3)$ & $0.14493(16)$ & $0.28458(14)$ & $0.14096(8)$ & $0.0180(4)$ \\
$\mathrm{N}(1)$ & $0.3543(6)$ & $-0.0137(5)$ & $0.0182(3)$ & $0.0130(12)$ \\
$\mathrm{N}(2)$ & $-0.1148(5)$ & $-0.0075(5)$ & $0.1576(3)$ & $0.0160(12)$ \\
$\mathrm{C}(1)$ & $0.4832(6)$ & $-0.0813(7)$ & $0.0350(3)$ & $0.0197(17)$ \\
$\mathrm{C}(2)$ & $0.3836(7)$ & $0.0826(6)$ & $-0.0342(3)$ & $0.0190(17)$ \\
$\mathrm{C}(3)$ & $0.2550(6)$ & $-0.1074(5)$ & $-0.0074(3)$ & $0.0163(17)$ \\
$\mathrm{C}(4)$ & $0.1133(7)$ & $-0.0497(6)$ & $-0.0103(3)$ & $0.0143(17)$ \\
$\mathrm{C}(5)$ & $0.0255(7)$ & $-0.0724(6)$ & $-0.0629(3)$ & $0.0190(17)$ \\
$\mathrm{C}(6)$ & $-0.1084(7)$ & $-0.0275(6)$ & $-0.0612(3)$ & $0.0187(17)$ \\
$\mathrm{C}(7)$ & $-0.1550(7)$ & $0.0337(7)$ & $-0.0060(3)$ & $0.0227(19)$ \\
$\mathrm{C}(8)$ & $-0.0692(6)$ & $0.0558(6)$ & $0.0460(3)$ & $0.0163(17)$ \\
$\mathrm{C}(9)$ & $0.0722(6)$ & $0.0218(6)$ & $0.0440(3)$ & $0.0147(16)$ \\
$\mathrm{C}(10)$ & $-0.1296(6)$ & $0.0979(6)$ & $0.1105(3)$ & $0.0170(16)$ \\
$\mathrm{C}(11)$ & $-0.2240(7)$ & $-0.1028(6)$ & $0.1492(3)$ & $0.0220(16)$ \\
$\mathrm{C}(12)$ & $-0.1225(7)$ & $0.0455(7)$ & $0.2248(3)$ & $0.0203(17)$ \\
$\mathrm{C}(13)$ & $0.2659(6)$ & $-0.0150(5)$ & $0.1715(3)$ & $0.0117(14)$ \\
$\mathrm{C}(14)$ & $0.3177(6)$ & $-0.0754(6)$ & $0.2319(3)$ & $0.0143(14)$ \\
$\mathrm{C}(15)$ & $0.3864(6)$ & $-0.2045(6)$ & $0.2163(3)$ & $0.0170(17)$ \\
$\mathrm{C}(16)$ & $0.2020(7)$ & $-0.0968(7)$ & $0.2803(3)$ & $0.0197(17)$ \\
$\mathrm{C}(17)$ & $0.4263(7)$ & $0.0154(6)$ & $0.2619(3)$ & $0.0197(17)$
\end{tabular}

$$
{ }^{a} U_{\infty q}=1 / 3 \sum_{i} \sum_{j} U_{i j} a_{i}^{*} a_{j}^{*} \mathbf{a}_{j} \mathbf{a}_{j} \text {. }
$$

C, 48.46; H, 5.94; N, 6.52. Found: C, 46.42; H, 5.81; N, 6.48.34 ${ }^{1} \mathrm{H}$ NMR (300.13 MHz, $\mathrm{C}_{6} \mathrm{D}_{6}, 25^{\circ} \mathrm{C}$, TMS): $\delta 1.57$ (s, $9 \mathrm{H}, t-\mathrm{Bu}$ ), $2.07,2.11,2.18$, and $2.36(4 \mathrm{~s}, 18 \mathrm{H}, \mathrm{NMe}), 2.65$ and $4.64\left(\mathrm{~d},{ }^{2} \mathrm{~J}\right.$ $\left.=11.8 \mathrm{~Hz}, 2 \times 1 \mathrm{H}, \mathrm{CH}_{2} \mathrm{~N}\right), 3.24$ and $4.27\left(2 \mathrm{~d},{ }^{2} \mathrm{~J}=13.1 \mathrm{~Hz}, 2\right.$ $\left.\times 1 \mathrm{H}, \mathrm{CH}_{2} \mathrm{~N}\right), 4.07$ and $4.43\left(2 \mathrm{~d},{ }^{2} \mathrm{~J}=16.4 \mathrm{~Hz}, 2 \times 1 \mathrm{H}, \mathrm{CH}_{2} \mathrm{~N}\right)$, $7.26(\mathrm{~m}, 5 \mathrm{H}, \mathrm{ArH}), 8.36\left(\mathrm{~d},{ }^{3} J=7.6 \mathrm{~Hz}, 1 \mathrm{H}, 0-\mathrm{H}\right.$ of $\left.\mathrm{C}_{6} \mathrm{H}_{3}\right), 9.44$ (dd, ${ }^{3} J=7.3 \mathrm{~Hz},{ }^{4} J=1.0 \mathrm{~Hz}, 1 \mathrm{H}, 0-\mathrm{H}$ of $\mathrm{C}_{6} \mathrm{H}_{4}$ ). ${ }^{18} \mathrm{C}\left\{{ }^{1} \mathrm{H}\right\} \mathrm{NMR}$ (75.47 MHz, $\left.\mathrm{C}_{6} \mathrm{D}_{6}, 25^{\circ} \mathrm{C}, \mathrm{TMS}\right): \delta 36.5\left[\mathrm{C}\left(\mathrm{CH}_{3}\right)_{3}\right], 47.3\left[\mathrm{C}\left(\mathrm{CH}_{3}\right)_{3}\right]$, 46.3, 48.4, 50.8, and $51.8\left(\mathrm{NCH}_{3}\right), 66.0,71.1$, and $71.7\left(\mathrm{CH}_{2} \mathrm{~N}\right)$, 125.2-158.6 (ArC), $203.8\left(\mathrm{C}_{\text {ipwo }}\right.$ of $\left.\mathrm{C}_{8} \mathrm{H}_{4}\right), 278.4$ (C-t-Bu).

Hydrolysis and Deuterolysis of 5. A stirred blue solution of 5 (ca. $10 \mathrm{mg}$ ) in $\mathrm{C}_{6} \mathrm{D}_{6}(0.5 \mathrm{~mL})$ was treated with a drop of $\mathrm{H}_{2} \mathrm{O}$ or $\mathrm{D}_{2} \mathrm{O}$ whereupon instantaneous decolorization occurred and a white precipitate formed. A drop of pyridine- $d_{5}$ was added and the mixture filtered through Celite to afford a colorless solution that was used for the FAB measurements.

$\mathrm{C}_{6} \mathrm{D}_{3} \mathrm{Me}_{2}-1,3-\mathrm{Br}-2$. A vigorously stirred mixture of 2-bromo1,3-dimethylbenzene $(37 \mathrm{~g}), \mathrm{D}_{2} \mathrm{SO}_{4}(22 \mathrm{~mL})$, and $\mathrm{D}_{2} \mathrm{O}(6 \mathrm{~mL})$ was heated at reflux for $3 \times 1 \mathrm{~min}$. (Prolonged reflux leads to thermal decomposition.) The reaction mixture was stirred at $20^{\circ} \mathrm{C}$ for $18 \mathrm{~h}$, and the resulting gray slush was diluted with $50 \mathrm{~mL}$ of $\mathrm{H}_{2} \mathrm{O}$. The organic product was subsequently extracted with $\mathrm{CCl}_{4}$ ( $3 \times$ $50 \mathrm{~mL}$ ), dried over $\mathrm{Na}_{2} \mathrm{SO}_{4}$, and purified by distillation; yield 20 g of $\mathrm{C}_{6} \mathrm{D}_{3} \mathrm{Me}_{2}-1,3-\mathrm{Br}-2$ with $90 \%$ deuterium enrichment of the three aryl hydrogens.

$\mathrm{TaCl}_{2}\left(\mathrm{C}_{6} \mathrm{H}_{4} \mathrm{CH}_{2} \mathrm{NMe}_{2}-2\right)\left[=\mathrm{C}(t-\mathrm{Bu})\left\{\mathrm{C}_{6} \mathrm{D}_{3}\left(\mathrm{CH}_{2} \mathrm{NMe}_{2}\right)_{2}-\right.\right.$ $2,6\}]$. $\mathrm{C}_{6} \mathrm{D}_{3} \mathrm{Me}-1,3-\mathrm{Br}$ as prepared above was used for the successive synthesis (six further steps) of $\mathrm{TaCl}_{2}\left(\mathrm{C}_{6} \mathrm{H}_{4} \mathrm{CH}_{2} \mathrm{NMe}_{2}-\right.$ 2) $\left[=\mathrm{C}(t-\mathrm{Bu})\left\{\mathrm{C}_{6} \mathrm{D}_{3}\left(\mathrm{CH}_{2} \mathrm{NMe}_{2}\right)_{2}-2,6\right\}\right]$ as described for its nondeuterated analogue 5 .

Crystal Structure Determination of 2. Crystal data and numerical details of the structure determination of 2 are given in Table II. X-ray data were collected for a red-brown crystal mounted on a glass fiber at $100 \mathrm{~K}$ on an Enraf-Nonius CAD4 diffractometer with $\mathrm{Zr}$-filtered Mo $\mathrm{K} \alpha$ radiation. The cell parameters were derived from the 25 SET4 setting angles with $15<\theta<18^{\circ}$. Intensity data were corrected for $L p$, a small linear decay of $1 \%$, and absorption (corrections 0.76:1.39) (DIFABS). ${ }^{36}$

(34) An explanation for the too low $C, H, N$ values found for this new complex is the incorporation of a little $\mathrm{ZnCl}_{2}$ that is coordinated by the "free" $\mathrm{CH}_{2} \mathrm{NMe}_{2}$ functions. Anal. Calcd for $5 \cdot 0.2 \mathrm{ZnCl}_{2}: \mathrm{C}, 46.49 ; \mathrm{H}$, $5.70 ; \mathrm{N}, 6.26$.

(35) Walker, N.; Stuart, D. Acta Crystallogr. 1983, A39, 158. 
The structure was solved for the heavy atoms with the TREF option of SHELXS-86se and subsequent difference Fourier syntheses and refined by full-matrix least squares techniques on $F .87$ All H-atoms were introduced at calculated positions with $\mathrm{C}-\mathrm{H}=1.08 \AA$ and refined riding on their carrier atom. Convergence was reached at $R=0.034, R_{w}=0.054$. Weights were based on counting statistics. One common isotropic therma parameter for $\mathrm{H}$-atoms was used. Scattering factors were taken from Cromer and Mann, ${ }^{38}$ and anomalous dispersion corrections, from Cromer and Liberman. ${ }^{39}$ Refinement of the enantiomorphous model resulted in the slightly higher $R=0.036$. Geometrical calculations and illustrations were done with the program

(36) Sheldrick, G. M. SHELXS86. Program for crystal structure determination. University of Góttingen, Federal Republic of Germany, 1986.

(37) Sheldrick, G. M. SHELX76. Crystal structure analysia package. University of Cambridge, England, 1976.

(38) Cromer, D. T.; Mann, J. B. Acta Crystallogr. 1968, A24, 321

(39) Cromer, D. T.; Liberman, D. J. Chem. Phys. 1970, 53, 1891.
PLATON.t0 All calculations were carried out on a MicroVax-II cluster. Final coordinates of the non-hydrogen atoms of 2 are given in Table III.

Acknowledgment. This work was supported in part (H.C.L.A. and A.L.S.) by the Netherlands Foundation for Chemical Research (SON) with financial aid from the Netherlands Organization for Scientific Research (NWO). We thank R. Hueber for recording the mass spectra and A. J. M. Duisenberg for collecting the X-ray data.

Supplementary Material Available: For 2, tables of hydrogen atom positions and isotropic thermal parameters, anisotropic thermal parameters, and complete bond distances and angles (5 pages). Ordering information is available on any current masthead page.

$0 \mathrm{M9300991}$

(40) Spek, A. L. Acta Crystallogr., Sect. A 1990, 46, C34. 